Ann. Génét. Sél. anim., I979, 11 (I), 23-5I.

\title{
Crossbreeding the Sardinian and East Friesian breeds in Sardinia
}

\author{
J. G. BOYAZOGLU $(*)$, S. CASU and J. C. FLAMANT $\left({ }^{* *}\right)$
}

with the technical collaboration of G. RUdA, G. PICINELII et R. CARTA

Istituto Zootecnico e Caseario per la Sardegna, Olmedo, Sassari, (Italy)

$\left(^{*}\right)$ Animal Production Department, Aristotelian University, Thessaloniki, (Greece)

(**) Station d'Amélioration Génétique des Animaux,

Centre de Recherches de Toulouse, I.N.R.A., 31320 Castanet, Tolosan (France).

\section{Summary}

The genetic improvement of the milk production and prolificacy of dairy ewe populations can be obtained through the crossbreeding and upgrading of the ewes of the local breed with imported male lines. Until recently, the most interesting breed for this purpose in the Mediterranean Basin has been the East Friesian.

More recent information (ZERVAS $e t$ al., I975; FlamanT et al., I976; Fox $e t$ al., 1976; KalaISSAKIS et al., I977; FLAMANT and CASU, 1977) indicates that one of the prolific Eastern Mediterranean dairy breeds might have been a better choice; particularly in the light of the general lack of adaptability of both the East Friesian and some of its crosses in most regions where the breed had been recently introduced outside its zone of origin (DOMINGOS BORREGO, I968; EYA I, and Goot, I968; RICORDEAU and Flamant, 1969a, $b$; TANEV et al., i971; KATSAOUNIS, I972; ZERVAS et al., I975; Goot, 1976; CUMlivski, 1976; F.A.O., I977; KALAISSAKIs et al., I977; SöNMEZ, 1977).

The purebred Friesian ewes adapt poorly to the dryland and high temperature conditions of the local ecosystem. Even with no nutritional deficiencies, as in the case of the intensively irrigated plain environment in Sardinia, it appears to be of no economic value to produce crossbred females with a Friesian blood component of over $50 \mathrm{p}$. Ioo for reproduction purposes.

Our observations in the present paper confirm information obtained from other similar experiments in the Mediterranean, i.e. that with more than $5^{\circ} \mathrm{p}$. Ioo Friesian blood, the same difficulties of adaptation as with the purebred East Friesian ewes tend to be found. No noteworthy increase in milk yield and prolificacy is obtained with a higher Friesian blood component. Our data, in fact, shows the $75 \mathrm{p}$. roo $\mathrm{Fr}$ to be less productive than the $50 \mathrm{p}$. roo $\mathrm{Fr}\left(\mathrm{F}_{1}\right)$, while there is no difference in productivity between the $25 \mathrm{p}$. I0O Fr and the purebred Sardas. 


\section{Introduction}

The Sarda ewe, which gives very satisfactory results under the typical extensive Mediterranean husbandry conditions in Sardinia, has four major limitations for intensive husbandry systems:

- a relatively low average level of milk production,

- a relatively small body size,

- a relatively low reproduction ability,

- limited growth capacity of the lambs, with poor carcass conformation.

To correct these deficiencies and to obtain an animal better adapted to the more intensive husbandry conditions of the lowlands, it was decided in the early sixties, as in other Mediterranean countries, to introduce the East Friesian for crossbreeding purposes. According to the bibliography known at the time (Scheingraber, I933, I934; Cremer, I934; MüHLBERG, I934; ZEEB, I934, I94I; EBbinghaus, I949; BuITKAMP, I952; GROENEVELd, I953; LANTINGA, I96r; STFPhan, I96r; Boyazoglu, I963; Dij KSTRA, I966), it appeared to be the most prolific and productive of the dairy breeds, despite its difficulty in adapting to high temperature dryland environments in the Mediterranean and para-Mediterranean zone (Dimakopoulos, i960; Goot, ig66; Tanev et al., ig68; Flamant and RICORDEAU, I969).

The development of irrigation and intensive pastures in Sardinia called for a more intensive system of dairy sheep husbandry than had hitherto been practised in these regions (CASU, I97I; BATICLE, I974). A major problem was to know whether the Sarda ewe could still be used successfully under these improved conditions or whether it would be better to replace her with a more productive kind of animal. A crossbreeding experiment was undertaken on the partly irrigated Bonassai experimental farm of the Istituto Zootecnico e Caseario per la Sardegna, situated in the Sassari plain (North-west Sardinia).

For purposes of comparison, a small flock of $I 7$ purebred Friesian ewes in lamb was introduced. As in other similar experiments elsewhere in the Mediterranean environment (FLAMANT and RICORDEAU, I969; FlAMANT, 1974), the adaptation of purebred East Friesian animals proved to be exceedingly poor. In this instance, half the ewas died during the first year; the remainder lambed and the mortality of the offspring in their first year was $80 \mathrm{p}$. Ioo.

It is important to stress that all the available information from the various Mediterranean experiments indicates that the Friesians initially show inadaptability, due to introductory stress in the new more arid environment. This could be bypassed, in some cases, by the importation of large populations, although it is doubtful whether this is economically valid. In this case, the so-called " routine or cruising mortality" would occur. "The mortality level is linked to the local climate, poor resistance to diseases (pulmonary, piroplasmosis) and parasites, and nutritional and management stress. In some cases, the Friesian disappears within a generation of its introduction, while in others it adapts better and survives, although still with a relatively high rate of mortality (ZERVAS et al., I975; FLAMANT et al., I975). 


\section{Material and methods}

The possibility of improving the production potential of the Sarda breed by crossbreeding to the East Friesian (Ostfriesisches Milchschaf) was studied from as early as $\mathrm{r} 966$. The crossbreeding experiments were not limited to the first generation $\left(\mathrm{F}_{1}\right)$, and back-crosses were also carried out to obtain $25 \mathrm{p}$. Ioo and 75 p. Ioo Friesian females, the objective being to compare these three female genotypes with purebred Sarda contemporaries. In order to obtain the four genotypes (Table I), seven Friesian (Fr), nine Sarda (S) and four crossbred rams (50 p. Ioo Fr) were used.

TABIE I

Number of breeding ewes

Effectifs des brebis

\begin{tabular}{|c|c|c|c|c|}
\hline Genotype $\quad$ First year of breeding & I967-I 968 & I968-I969 & I969-I970 & Total \\
\hline 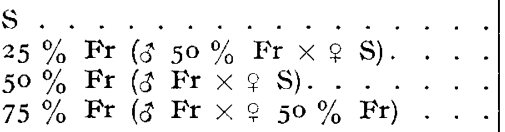 & 55 & $\begin{array}{l}36 \\
43\end{array}$ & $4^{8}$ & $\begin{array}{r}\text { I } 39 \\
43 \\
54 \\
22\end{array}$ \\
\hline 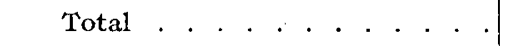 & I 09 & 79 & $7^{\circ}$ & 258 \\
\hline
\end{tabular}

Because of the considerable climatic variability from one year to another in the Mediterranean region, a contemporary system of comparison was imperative. Thus, each of the groups of crossbred ewes (25 p. IOo Fr, 50 p. IOo Fr, 75 p. IOO Fr) was compared with a contemporary group of Sarda $(\mathrm{S})$ animals, always originating from the same flock.

Management conditions never varied during the experiment: intensive pasture (oats, lucerne, rye-grass, clover, etc.), with a maximum daily dose of $500 \mathrm{~g}$ of concentrates per ewe during the winter months, if necessary. These conditions are thus typical of the intensive irrigated regions of the Mediterranean Basin. Milking was carried out by machine without hand stripping $\left({ }^{1}\right)$. From the total available population (ewes having completed four lactations), 258 ewes were chosen at random for this study. There was no planned selection programme, so as to allow free interplay of the normal genetic population factors.

Lambs were weighed at birth and then weekly until weaning at an average age of 35 days; thereafter, they were weighed monthly. Continuous observations on the reproduction of the ewes were carried out during the breeding season (individual mating). Milk yield and protein and fat content of the milk were measured twice monthly, starting after weaning. The first recording was made during the second month of lactation, but in most cases, 40 to 45 days after lambing. Both the total lactation yield and the standard refərence lactation yield over I5O days of milking (I20 days for the first lactation) were calculated.

(1) As defined at the International Symposium on the Machine Milking of Small Ruminants, Alghero, Sardinia, May 1978 . 
For the present paper, only the results of four consecutive complete lactations were taken from the data obtained over the ten years of the study, except when otherwise indicated (e.g. the comparisons of wool quality). As far as more specific evaluation methods are concerned, the means and standard deviations were evaluated in all cases, while an attempt was made, where necessary, to express the averages (in percentage) of the different crossbred populations in relation to their contemporary purebred Sarda populations (taken as roo p. IOo) and to calculate the necessary standard errors.

Figure I gives a complete explanatory reference of the body measurements, while the classification used for the udder conformation is presented in figure 4 . The live weights of the ewes were measured at lambing and shearing.

In 1976 , fleeces from a random sample of 15 adult ewes of each of the four genotypes were weighed at shearing and samples of the wool were analysed for staple length, crimping, percentage clean wool and fibre thickness at the wool laboratory of the S.A.A.D.S.R.I. $\left({ }^{2}\right)$ by the standard methods normally used.

\section{Results}

\section{a. - Ewe weight and body measurements}

While there is generally little difference in weight between the $25 \mathrm{p}$. roo Fr and the comparable Sarda ewes, the 50 p. Ioo Fr animals are significantly heavier at first œstrus than the comparable Sarda purebreds (table 2).

TABI,E 2

First astrus

Premièves chaleurs

\begin{tabular}{|c|c|c|c|c|c|c|c|c|c|}
\hline \multirow[b]{3}{*}{ Genotype } & \multicolumn{3}{|c|}{ 1968-1969 } & \multicolumn{3}{|c|}{ I969-1970 } & \multicolumn{3}{|c|}{$1970-197 \mathrm{I}$} \\
\hline & \multirow[b]{2}{*}{$\mathrm{N}$} & \multicolumn{2}{|c|}{ Ist œstrus } & \multirow[b]{2}{*}{$\mathrm{N}$} & \multicolumn{2}{|c|}{ I st cestrus } & \multirow[b]{2}{*}{$\mathrm{N}$} & \multicolumn{2}{|c|}{ Ist œstrus } \\
\hline & & $\begin{array}{l}\text { Age } \\
\text { (days) }\end{array}$ & $\begin{array}{c}\text { Live- } \\
\text { weight } \\
(\mathrm{kg})\end{array}$ & & $\begin{array}{l}\text { Age } \\
\text { (days) }\end{array}$ & $\begin{array}{c}\text { Live- } \\
\text { weightt } \\
\left(\mathrm{kg}^{\prime}\right)\end{array}$ & & $\begin{array}{c}\text { Age } \\
\text { (days) }\end{array}$ & $\begin{array}{c}\text { Live- } \\
\text { weight } \\
\text { (kg) }\end{array}$ \\
\hline S & 55 & $\begin{array}{c}303 \\
(100 \%)\end{array}$ & $\begin{array}{c}32,7 \\
(100 \%)\end{array}$ & $3^{6}$ & $\begin{array}{c}295 \\
(100 \%)\end{array}$ & $\begin{array}{c}32,3 \\
(100 \%)\end{array}$ & $4^{8}$ & $\begin{array}{c}269 \\
(100 \%)\end{array}$ & $\begin{array}{c}34,4 \\
(100 \%)\end{array}$ \\
\hline $25 \% \mathrm{Fr}$. & & & & 43 & $\begin{array}{c}264 \\
(90 \%)\end{array}$ & $\begin{array}{c}32,0 \\
(99 \%)\end{array}$ & & & \\
\hline $50 \% \mathrm{Fr}$ & 54 & $\begin{array}{c}263 \\
(87 \%)\end{array}$ & $\begin{array}{c}36,8 \\
\text { (I } 13 \% \text { ) }\end{array}$ & & & & & & \\
\hline $75 \%$ Fr. & & & & & & & 22 & $\begin{array}{c}238 \\
(89 \%)\end{array}$ & $\begin{array}{c}44,9 \\
(\mathrm{r} 30 \%)\end{array}$ \\
\hline
\end{tabular}

(2) South African Animal and Darry Sciences Research Institute. 
There is also no real difference between the lambing and shearing weights of the $25 \mathrm{p}$. IOO Fr and the contemporary purebreds for all four lactations. Upgrading towards $50 \mathrm{p}$. IOO $\mathrm{Fr}$ and $75 \mathrm{p}$. IOo $\mathrm{Fr}$ is, however, always followed by a considerable increase in body size. This confirms the advantage of introducing heavier breeds to obtain females of better size and conformation than the ones traditionally found in the Mediterranean (table 3). The heavier adult weights of the upgraded crossbred animals are in line with the weights at first œstrus, the 50 p. I Oo Fr and 75 p. Ioo Fr crossbreds in all cases being much heavier than their purebred contemporaries.

TABLE 3

Age, gestation period and liveweight at lambing and at shearing (indicative)

Age, durée de gestation et poids vif à la mise-bas et à la tonte (valeurs indicatives)

\begin{tabular}{|c|c|c|c|c|c|c|c|c|c|}
\hline \multirow{2}{*}{\multicolumn{2}{|c|}{$\begin{array}{l}\text { Variable } \\
\text { Lactation } \\
\text { and genotype }\end{array}$}} & \multicolumn{2}{|c|}{$\begin{array}{l}\text { Liveweight } \\
\text { at lambing } \\
\text { (kg) }\end{array}$} & \multicolumn{2}{|c|}{$\begin{array}{c}\text { Gestation } \\
\text { per. } \\
\text { (days) }\end{array}$} & \multicolumn{2}{|c|}{$\begin{array}{c}\text { Age } \\
\text { at lambing } \\
\text { (months) }\end{array}$} & \multicolumn{2}{|c|}{$\begin{array}{c}\text { Liveweight } \\
\text { at shearing } \\
(\mathrm{kg})\end{array}$} \\
\hline & & $\bar{x} \pm$ S.E. & $t$-Test & $\bar{x} \pm$ S.E. & $t$-Test & $\bar{x} \pm$ S.E. & $t$-Test & $\bar{x}$ & $t$-Test \\
\hline \multirow{3}{*}{ 荡 } & $\begin{array}{l}\mathrm{S} \\
25 \% \mathrm{Fr}\end{array}$ & $\begin{array}{l}38,1 \pm 0,8 \\
38,6 \pm 0,7 \\
\end{array}$ & N.S. & $\begin{array}{l}\mathbf{I} 49,4 \text { 上 } 0,6 \\
\mathrm{I} 48,6 \pm 0,4 \\
\end{array}$ & N.S. & $\begin{array}{l}\mathrm{I} 5, \mathrm{I} \pm 0, \mathrm{I} \\
\mathrm{I} 4,2 \pm 0, \mathrm{I} \\
\end{array}$ & $* *$ & $\begin{array}{l}40,7 \\
40,8 \\
\end{array}$ & N.S. \\
\hline & $\begin{array}{llllll}\mathrm{S} & - & & & \\
50 & \% & \mathrm{Fr} & & \\
\end{array}$ & $\begin{array}{l}36,0 \pm 0,8 \\
45, \mathrm{I} \pm 0,8 \\
\end{array}$ & $* *$ & $\begin{array}{l}\mathrm{I} 49,4 \pm 0,5 \\
\mathrm{r} 47,5 \pm 0,3 \\
\end{array}$ & $* *$ & $\begin{array}{l}\mathrm{I} 6,2 \pm 0, \mathrm{I} \\
\mathrm{I} 5,2 \pm 0,2\end{array}$ & $* *$ & $\begin{array}{l}34,7 \\
44,1\end{array}$ & $* *$ \\
\hline & 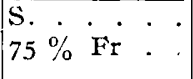 & $\begin{array}{l}37,1 \pm 0,7 \\
50,6 \pm 1,5\end{array}$ & $* *$ & \begin{tabular}{|l|}
$448,8 \pm 0,5$ \\
$145,5 \pm 0,8$
\end{tabular} & ** & $\begin{array}{l}13,7 \pm 0,2 \\
14,5 \pm 0,2\end{array}$ & * & $\begin{array}{l}39,7 \\
53, \mathrm{I}\end{array}$ & $* *$ \\
\hline \multirow{3}{*}{$\begin{array}{l}\overrightarrow{0} \\
\text { : } \\
\ddot{8}\end{array}$} & 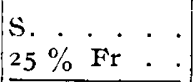 & $\begin{array}{l}4^{\mathrm{I}, 4} \pm 0,7 \\
4^{\mathrm{I}, 9} \pm \mathrm{I}, \mathrm{O}\end{array}$ & N.S. & $\mid \begin{array}{l}149,5 \\
148,1\end{array}$ & N.S. & $\begin{array}{l}25,0 \pm 0,2 \\
24,7 \pm 0,2\end{array}$ & N.S. & $\begin{array}{l}46,5 \\
45,9\end{array}$ & N.S. \\
\hline & $\begin{array}{llllll}\mathrm{S} & & & & & \\
50 & \% & \mathrm{Fr} & . & \\
\end{array}$ & $\begin{array}{r}45,5 \pm 0,9 \\
55,9 \pm 0,8 \\
\end{array}$ & $* *$ & $\begin{array}{l}44,4 \pm 0,4 \\
145,5 \pm 0,3 \\
\end{array}$ & N.S. & $\begin{array}{l}26,0 \pm 0,2 \\
27,1 \pm 0,7 \\
\end{array}$ & N.S. & $\begin{array}{l}46,8 \\
56,6\end{array}$ & $* *$ \\
\hline & $\begin{array}{llll}S & 0 & & \\
75 & \% & \mathrm{Fr} & \\
\end{array}$ & $\begin{array}{l}43,0 \pm \mathrm{I}, \mathrm{I} \\
55,2 \pm \mathrm{I}, 9\end{array}$ & $* *$ & $\mid \begin{array}{l}\mathrm{I} 48,3 \pm 0,6 \\
\mathrm{I} 44,8 \pm 0,9\end{array}$ & $*$ & $\begin{array}{l}25,0 \pm 0,3 \\
24,5 \pm 0,2\end{array}$ & N.S. & $\begin{array}{l}45,4 \\
64,4\end{array}$ & $* *$ \\
\hline \multirow{3}{*}{ 蛋 } & $\begin{array}{lllll}S . & 0 & & \\
25 & \% & \mathrm{Fr} & \\
\end{array}$ & $\begin{array}{l}46,0 \pm 0,8 \\
48,5 \pm 1,0 \\
\end{array}$ & N.S. & $\begin{array}{l}\mathbf{r} 48,3 \pm 0,9 \\
\mathbf{r} 47,5 \pm 0,6\end{array}$ & N.S. & $\begin{array}{l}37,2 \pm 0,2 \\
35,7 \pm 0,2\end{array}$ & $* *$ & $\begin{array}{l}50,2 \\
53,9 \\
\end{array}$ & * \\
\hline & $\begin{array}{lllll}\mathrm{S} & \% & \mathrm{~F} & \\
50 & \% & \mathrm{Fr} & \\
\end{array}$ & $\begin{array}{l}43,4 \pm 0,9 \\
52,0 \pm 0,8\end{array}$ & $* *$ & $\begin{array}{l}\mathrm{I} 48, \mathrm{I} \pm 0,4 \\
\mathrm{I} 46,3 \pm 0,5\end{array}$ & * & $\begin{array}{l}37,0 \pm 0,2 \\
36,0 \pm 0,2\end{array}$ & $* *$ & $\begin{array}{l}46,5 \\
58,2\end{array}$ & ** \\
\hline & $\begin{array}{llllll}\mathrm{S} & . & & & \\
75 & \% & \mathrm{Fr} & . & \\
\end{array}$ & $\begin{array}{l}44, \mathrm{I} \pm 1,3 \\
58,3 \pm \mathrm{r}, 6\end{array}$ & $* *$ & $\begin{array}{l}146,7 \pm 0,3 \\
144,9 \pm 0,5\end{array}$ & $* *$ & $\begin{array}{l}35,7 \pm 0,2 \\
36,1 \pm 0,1\end{array}$ & N.S. & - & \\
\hline \multirow{3}{*}{ 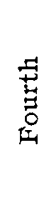 } & $\begin{array}{llllll}\mathrm{S} . & \circ & \mathrm{C} & & \\
25 & \% & \mathrm{Fr} & & \\
\end{array}$ & $\begin{array}{l}47,7 \pm \mathrm{I}, \mathrm{I} \\
48,3 \pm \mathrm{I}, 3 \\
\end{array}$ & $* *$ & 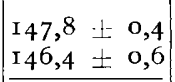 & N.S. & $\begin{array}{l}48,2 \pm 0,1 \\
47,6 \pm 0,2 \\
\end{array}$ & N.S. & - & \\
\hline & $\begin{array}{lllll}\mathrm{S} & & & & \\
50 & \% & \mathrm{Fr} & & \\
\end{array}$ & $\begin{array}{l}45,9 \pm \mathrm{r}, \mathrm{o} \\
56,6 \pm 0,9 \\
\end{array}$ & $* *$ & $\begin{array}{l}146,9 \pm 0,5 \\
145,5 \pm 0,3 \\
\end{array}$ & * & $\begin{array}{l}48,7 \pm 0,2 \\
47,9 \pm 0,2 \\
\end{array}$ & * & $\begin{array}{l}49,6 \\
59,0\end{array}$ & $* *$ \\
\hline & 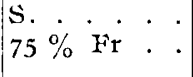 & $\begin{array}{l}50,3 \pm \mathrm{I}, 2 \\
60,9 \pm \mathrm{I}, 8\end{array}$ & $* *$ & $\begin{array}{l}148,2 \pm 0,5 \\
145,4 \pm 0,5\end{array}$ & $* *$ & $\begin{array}{l}47,4 \pm 0,2 \\
48,0 \pm 0,2\end{array}$ & N.S. & 二 & \\
\hline
\end{tabular}


A representative number of one-year old ewes from the different genotypes were measured (fig. I) and the various body measurements and live weights recorded as an indication of the conformation changes obtained through crossbreeding (table 4).

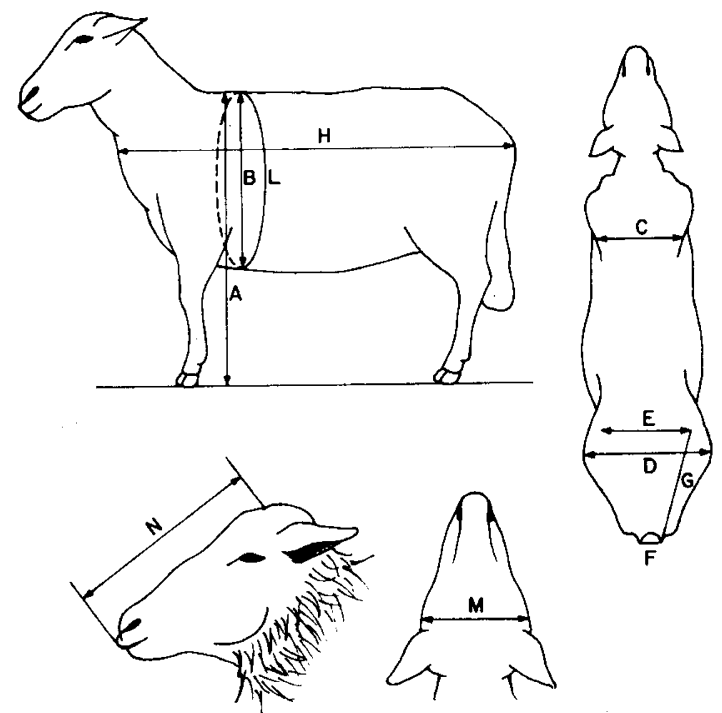

FIG. I. - Measurements.

Mensurations.

TABLE 4

Measurements $(\mathrm{cm})$ of the breeding ewes at one year of age (see fig. I) Mensurations $(\mathrm{cm})$ des brebis à l'âge d'un an (voir fig. I)

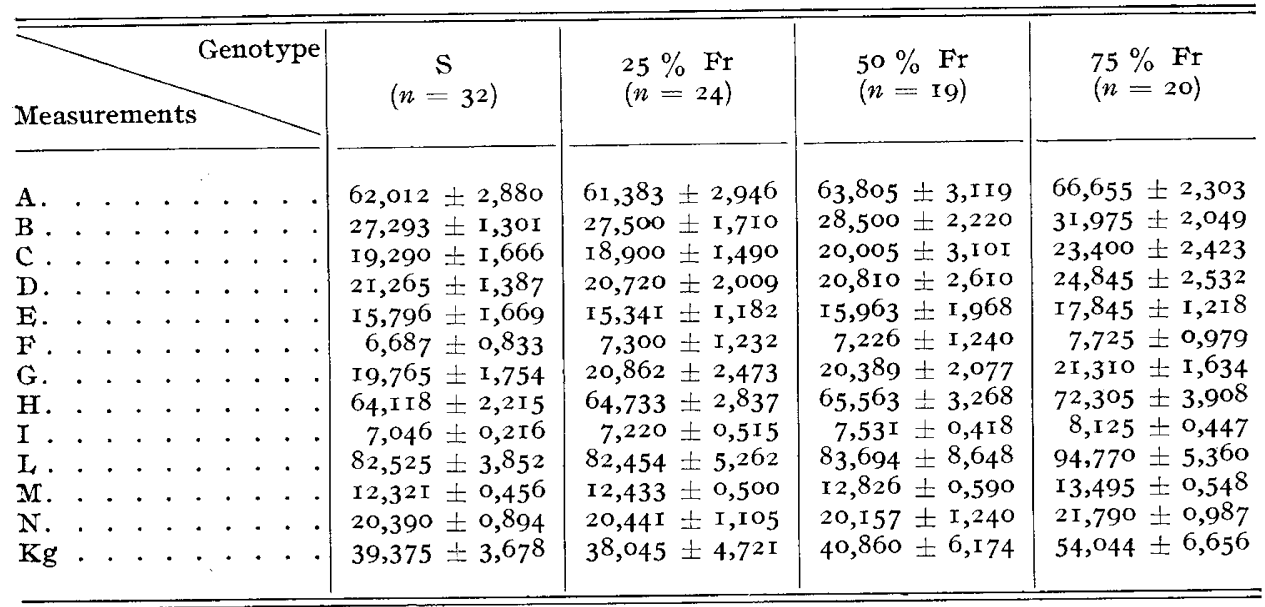




\section{b. - Precocity, gestation and lambing}

From tables 2 and 3 , the following values can te obtained when expressing the ewes' live weight at first cestrus as a percentage of their weight at fourth lambing $(\mathrm{kg})$, which is considered as indicative of precocity:

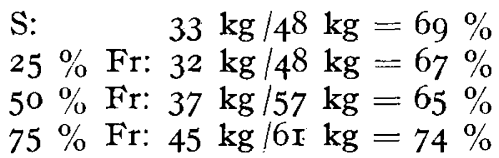

Thus, as previously shown by HAFEZ (I953) and WALRAVE et al. (I975), there is little variation between the purebreds (Sarda) and the $25 \mathrm{p} .100$ and $50 \mathrm{p}$. Ioo (Friesian) crossbreds, with a slightly better precocity for the $\mathrm{F}_{\mathbf{1}}$ as compared with the Sardas (first œstrus at a lower weight as a percentage of the adult weight). The extremely high percentage (74 p. I0o) obtained for the upgraded ( $75 \mathrm{p}$. roo $\mathrm{Fr}$ ) ewes, which could be interpreted as an indication of poor precocity, is contrary to all expectations. This could, however, be the result of the small numbers (22 ewes) involved.

A better indication of sexual precocity is probably the age at first estrus, which gives very coherent average results:

$$
\begin{aligned}
& \text { S: } 270-300 \text { days } \\
& 25 \% \text { and } 50 \% \text { Fr: } \pm 263 \text { days } \\
& 75 \% \text { Fr: } \quad \pm 238 \text { days }
\end{aligned}
$$

When compared with their contemporary Sardas, the crossbreds show a pronounced tendency for an earlier first œestrus, from just over a ro p. roo difference for the $25 \mathrm{p}$. IOo Fr to I3 p. IOO for the $50 \mathrm{p}$. IOo Fr and over II p. Ioo for the $75 \mathrm{p}$. Ioo $\mathrm{Fr}$. This is confirmed by an earlier average age at first lambing for all groups of crossbred females, when compared within years, to the contemporary purebred groups (table 2 ). An interesting feature is the highly significant difference in age at first lambing (table 3 ), to the advantage of the less upgraded crossbreds ( $25 \mathrm{p}$. IOO Fr and $50 \mathrm{p}$. IOO Fr).

The gestation period of the purebred Sarda is longer (in most cases significantly longer) than that of all crossbred groups (table 3). Our data confirms the results obtained in Greece by Zervas et al. (I975), when comparing the Friesian. (I46 days) and its crosses (I47 days) with the local Chios sheep (I50 days). The gestation period of the Sarda was, with few exceptions, between I48-I50 days, while that of the crossbreds was I44-I46 days.

In Southern France, Flamant and Jacguin (I978) obtained very similar results (purebreds):

$$
\begin{array}{lll}
\text { I } 2 \text { Lacaune, adult ewes: } & \text { I } 47,8 \text { days } \\
\text { I12 Lacaune, one year old: } & \text { I } 46,8 \text { days } \\
\text { I32 Sarda, adult ewes: } & \text { I } 49, \text { I days } \\
40 \text { Sarda, one year old: } & \text { I } 48,9 \text { days }
\end{array}
$$

The purebred Sardas always lamb later in the season (also longer lactation) than the $25 \mathrm{p}$. Ioo Fr and the $50 \mathrm{p}$. Ioo Fr. The situation is reversed when comparing the $75 \mathrm{p}$. roo Fr with its contemporary Sarda. This could naturally be confounded with a year effect. It can be considered as an indication of the lower adap- 
tability of the more upgraded ewes ( 75 p. Ioo Fr) to local environmental conditions (despite good feeding and the particularly favourable year in which they were bred).

As in most other Southern European countries, the lambing season extends from October to early April (fig. 2). Contrary to the results obtained in Greece (ZERVAS et al., I975), there is no important difference between the ewes of the local breed and the crossbreds (not even the $75 \mathrm{p}$. roo Fr). The adult crossbred ewes (2nd, 3rd and 4th lactation), however, generally tend to lamb earlier on average than the purebred Sardas. 'The results obtained by MANnUTA and CASU (I.968) suggest that the Sarda is more seasonal in its breeding than other Mediterranean breeds.

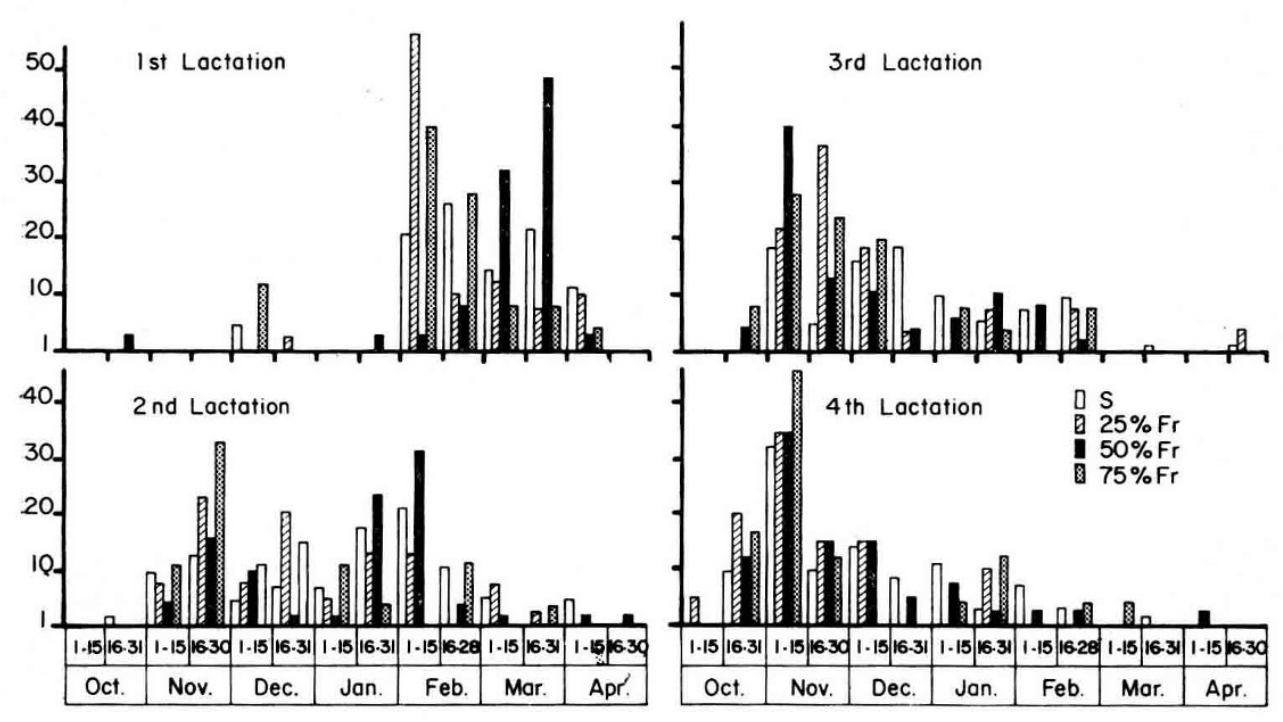

FIG. 2. - Distribution of lambing dates.

Distribution des dates d'agnelage.

\section{c. - Numerical productivity and viability}

There was little difference between the purebred Sarda ewes and the crossbreds in the percentage of ewes pregnant. However, there is apparently a slightly lower percentage of ewes actually lambing in the case of the crossbreds, particularly the $75 \mathrm{p}$. Ioo Fr and $50 \mathrm{p}$. Ioo Fr, when compared to their contemporary Sardas. The most interesting feature, though, is the high prolificacy of the crossbreds. The $25 \mathrm{p}$. Ioo Fr are slightly superior to the Sarda ewes, but the $50 \mathrm{p}$. Ioo Fr and 75 p. roo Fr are significantly better (table 5).

It is important to note the high percentage of early lamb mortality in the 75 p. Ioo Fr group and the continued rise in total lamb mortality, up to one year of age, with the higher proportions of Friesian blood (table 6), despite almost optimum intensive husbandry conditions. Data on the reasons for lamb mortality (table 7) show the main cause of death to be respiratory diseases. The limited available data on purebred Friesians on the farm is even more conclusive, as 


\section{I.N.R.A. - C.N.R.Z. \\ Département de Génétiqua Anlmalo \\ BIBLIOTHĖQUE \\ F 78350 JOUY EN JOSAS \\ SARDINIAN AND EAST FRIESIAN CROSSES

TABLE 5

Reproduction data

Données de reproduction

\begin{tabular}{|c|c|c|c|c|c|c|c|}
\hline $\begin{array}{l}\text { Lac- } \\
\text { tation }\end{array}$ & $\left({ }^{*}\right)$ Characteristics & $\mathrm{s}$ & $25 \% \mathrm{Fr}$ & $\mathrm{s}$ & $50 \% \mathrm{Fr}$ & $\mathbf{S}$ & $75 \% \mathrm{Fr}$ \\
\hline $\begin{array}{l}\overrightarrow{0} \\
\stackrel{5}{*}\end{array}$ & $\begin{array}{l}\text { Pregnant }(\%) . \\
\text { Lambed }(\%): \\
\text { Lambs born }(\%)\end{array}$ & $\begin{array}{l}80,55 \\
80,55 \\
94,44\end{array}$ & $\begin{array}{r}92,86 \\
92,86 \\
104,76\end{array}$ & $\begin{array}{l}80,00 \\
67,27 \\
80,43\end{array}$ & $\begin{array}{r}85, \mathrm{I} 8 \\
77,78 \\
\mathrm{I} 16,66\end{array}$ & $\begin{array}{r}97,92 \\
95,83 \\
102,08\end{array}$ & $\begin{array}{r}84,21 \\
78,95 \\
131,58\end{array}$ \\
\hline ": & 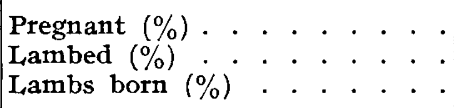 & $\begin{array}{r}88,89 \\
88,89 \\
\mathbf{1} \mathbf{3}, 88\end{array}$ & $\begin{array}{r}97,5^{\circ} \\
97,5^{\circ} \\
142,5^{\circ}\end{array}$ & $\begin{array}{r}97,06 \\
97,06 \\
\text { I I } 1,76\end{array}$ & $\begin{array}{r}96,15 \\
96,15 \\
136,54\end{array}$ & $\begin{array}{r}97,14 \\
80,00 \\
100,00\end{array}$ & $\begin{array}{r}100,00 \\
75,00 \\
125,00\end{array}$ \\
\hline 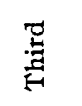 & $\begin{array}{l}\text { Pregnant }(\%) . \\
\text { Lambed }(\%) \\
\text { Lambs born }(\%)\end{array}$ & $\begin{array}{r}96, \mathrm{I} 5 \\
96,15 \\
130,76\end{array}$ & $\begin{array}{r}100,00 \\
96,30 \\
151,85\end{array}$ & $\begin{array}{r}90,70 \\
90,70 \\
130,23\end{array}$ & $\begin{array}{r}100,00 \\
97,92 \\
170,83\end{array}$ & $\begin{array}{r}96,43 \\
96,43 \\
+35,71\end{array}$ & $\begin{array}{l}\text { 100,00 } \\
\text { 100,00 } \\
\text { 1 } 78,57\end{array}$ \\
\hline 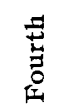 & $\begin{array}{l}\text { Pregnant }(\%) . . \\
\text { Lambed }(\%): . \\
\text { Lambs born }(\%)\end{array}$ & $\begin{array}{l}100,00 \\
100,00 \\
147,83\end{array}$ & $\begin{array}{r}90,48 \\
90,48 \\
\mathbf{1} 66,67\end{array}$ & $\begin{array}{l}\text { roo,oo } \\
100,00 \\
\text { r } 54,17\end{array}$ & $\begin{array}{r}100,00 \\
93,02 \\
162,79\end{array}$ & $\begin{array}{r}95,83 \\
95,83 \\
129,17\end{array}$ & $\begin{array}{r}92,86 \\
92,86 \\
192,86\end{array}$ \\
\hline
\end{tabular}

(*) Expressed as a percentage of the ewes served.

TABLE 6

Death rates from birth to one year old expressed as a percentage of lambs born (alive and stillborn) Mortalité de la naissance à un an, exprimée en pourcentage des agneaux nés (vivants et morts-nés)

\begin{tabular}{|c|c|c|c|c|c|}
\hline Genotype & $\begin{array}{c}0-4 \text { days } \\
(\%)\end{array}$ & $\begin{array}{l}4 \text { days- } \\
\text { weaning } \\
(\%)\end{array}$ & $\begin{array}{c}\text { Weaning } \\
\text { shearing } \\
(\%)\end{array}$ & $\begin{array}{c}\text { Shearing- } \\
\text { I year } \\
(\%)\end{array}$ & $\begin{array}{c}\text { O-I year } \\
(\%)\end{array}$ \\
\hline . . . & 3,62 & 2,47 & 2,08 & 一 & $8, \mathrm{I} 7\left(^{*}\right)$ \\
\hline $25 \% \mathrm{Fr}$ & 4,53 & 3,52 & $2,5 \mathrm{I}$ & - & 10,55 \\
\hline $50 \% \mathrm{Fr} .$. & 3,18 & 5,56 & - & 3,17 & $11,9^{\circ}$ \\
\hline $75 \% \mathrm{Fr} \cdot \ldots$ & $9, \mathbf{I} 9$ & 2,56 & $\mathrm{I}, \mathrm{OO}$ & 3,56 & 15,87 \\
\hline
\end{tabular}

(*) The average death rate from I 455 lambings of the Institute's purebred Sardinian flock for the years r 968 -1970 was 9,42 p. 100 .

$77,78 \mathrm{p}$. Ioo of all lambs born died with a year of birth (6I,II p. Ioo due to respiratory diseases). This information confirms our previous findings in Greece (ZERVAS et al., I975) and that of other authors (SHIMSHONI and LAVI, I972; FLAMANT, I974). When considering all lambings during the experimental period, we find 94 lambs weaned for every roo Sarda ewes originally available for kreeding, while the respective values for the crossbreds were II 5 for the $25 \mathrm{p}$. Ioo Fr, I63 for the $50 \mathrm{p}$. Ioo Fr and Iro for the $75 \mathrm{p}$. Ioo Fr. 
TABLE 7

Causes of death (indicative information only) from birth to one year old (\% of lambs born) Causes de mortalité (valeurs indicatives seulement), de la naissance à l'âge d'un an (\% d'agneaux nés)

\begin{tabular}{|c|c|c|c|c|c|c|c|}
\hline Genotype Causes & $\begin{array}{l}\text { Still- } \\
\text { born } \\
(\%)\end{array}$ & $\begin{array}{c}\text { Enteritis } \\
\text { and } \\
\text { coccidiosis } \\
(\%)\end{array}$ & $\begin{array}{c}\text { Respira- } \\
\text { tory } \\
\text { diseases } \\
(\%)\end{array}$ & $\begin{array}{l}\text { Blood } \\
\text { pois. } \\
(\%)\end{array}$ & $\begin{array}{l}\text { Entero- } \\
\text { toxemia } \\
(\%)\end{array}$ & $\begin{array}{c}\text { Others } \\
(\%)\end{array}$ & $\begin{array}{c}\text { Total } \\
(\%)\end{array}$ \\
\hline s. . . . & 0,96 & 2,00 & 0,46 & $2,4^{\circ}$ & I, 68 & 0,72 & 8,17 \\
\hline $25 \% \mathrm{Fr}$ & 2,27 & 2,29 & 2,27 & 2,20 & 1,52 & - & 10,55 \\
\hline $50 \% \mathrm{Fr}$. & $\mathrm{r}, 30$ & $\mathrm{I}, 98$ & $3, \mathbf{I} 7$ & $\mathbf{I}, 95$ & 2,60 & 0,90 & II, 90 \\
\hline $75 \%$ Fr & $3, \mathrm{I} 7$ & 4,80 & 7,90 & - & - & 一 & I 5,87 \\
\hline
\end{tabular}

\section{d. - Lamb growth rates and fattening}

The growth rates of the different genotypes, from birth to weaning, obtained by the average weights of all lambs born on the experimental farm of Bonassai during the experimental period (table 8) confirm the possibility of obtaining much heavier lambs, particularly from the $F_{1}$ genotype. This data coincides with that of Papadopoulos et al. (I972), obtained in Greece during a similar project, when crossbreeding the local Chios to the East Friesian.

One of the more positive results obtained through crossbreeding the Sarda to the East Friesian is that of body size, better growth rates and the obtention of crossbred male lambs more suitable for modern fattening techniques. The production of heavier lamb carcasses is naturally particularly interesting on the European continent where heavy lambs are more acceptable than on the island where the " agnello di latte" of 8-ro kg remains the consumer's choice.

An experimental attempt to evaluate the fattening potential of the crossbreds (SANNA and RUdA, I970; Cossedu et al., I972; CASU et al., I976) confirmed the better growth potential and daily weight gains of these animals, when using both barley and maize rations; a very interesting feature was the better carcass conformation of the crosstred lambs.

\section{e. - Milk production and culling}

An attempt was made to study the causes of culling of the different genotypes, taking into consideration the number of ewes of each group originally available and their performance to the end of the fourth. lactation. There has to date been no conclusive indication between the different genotypes, although the most important reason for culling appears to be udder conformation and the related sanitary problems (table 9). Information on the milking period is presented in 
TABLE 8

Growth rates

Taux de croissance

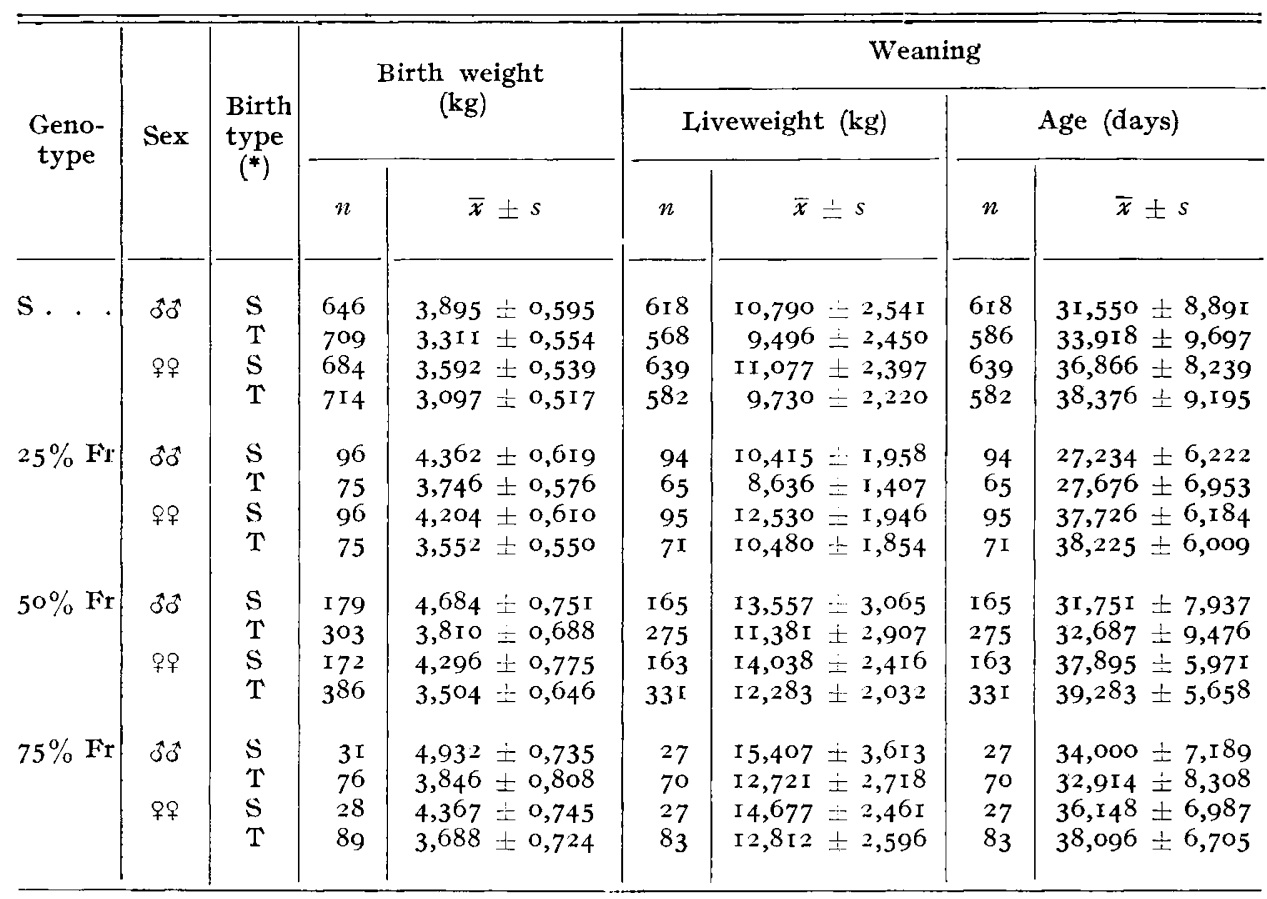

(*) Single (S) and twin (T) births.

TABLE 9

Causes of culling up to the 4 th lactation

(expressed as a percentage of the original numbers of breeding ewes)

Causes de réforme jusqu'à la $4^{\mathrm{e}}$ lactation

(exprimée en pourcentage du nombre de brebis présentes au départ)

\begin{tabular}{|c|c|c|c|c|c|c|}
\hline Causes $\quad \begin{array}{c}\text { Comparison of } \\
\text { genotypes }\end{array}$ & $\mathrm{S}(\%)$ & $25 \% \mathrm{Fr}$ & S $(\%)$ & $50 \% \mathrm{Fr}$ & S (\%) & $75 \% \mathrm{Fr}$ \\
\hline $\begin{array}{l}\text { Mastitis. } \\
\text { Other udder problems } \\
\text { Low productivity } \\
\text { Accidents. } . . . \\
\text { Others . . . . . . . . . . . }\end{array}$ & $\begin{array}{r}2,86 \\
\mathrm{II}, 43 \\
5,7 \mathrm{I} \\
- \\
-\end{array}$ & $\begin{array}{r}2,38 \\
26,19 \\
2,38 \\
-\end{array}$ & $\begin{array}{r}6,52 \\
19,57 \\
2,17 \\
2,17\end{array}$ & $\begin{array}{r}4,34 \\
15,22 \\
- \\
6,51\end{array}$ & $\begin{array}{l}\overrightarrow{6,82} \\
\overrightarrow{2,27} \\
4,54\end{array}$ & $\begin{array}{l}5,71 \\
2,86 \\
2,86 \\
-2,86\end{array}$ \\
\hline Total. & 20,00 & 33,95 & $3^{\circ}, 43$ & 26,07 & I 3,63 & 14,29 \\
\hline
\end{tabular}




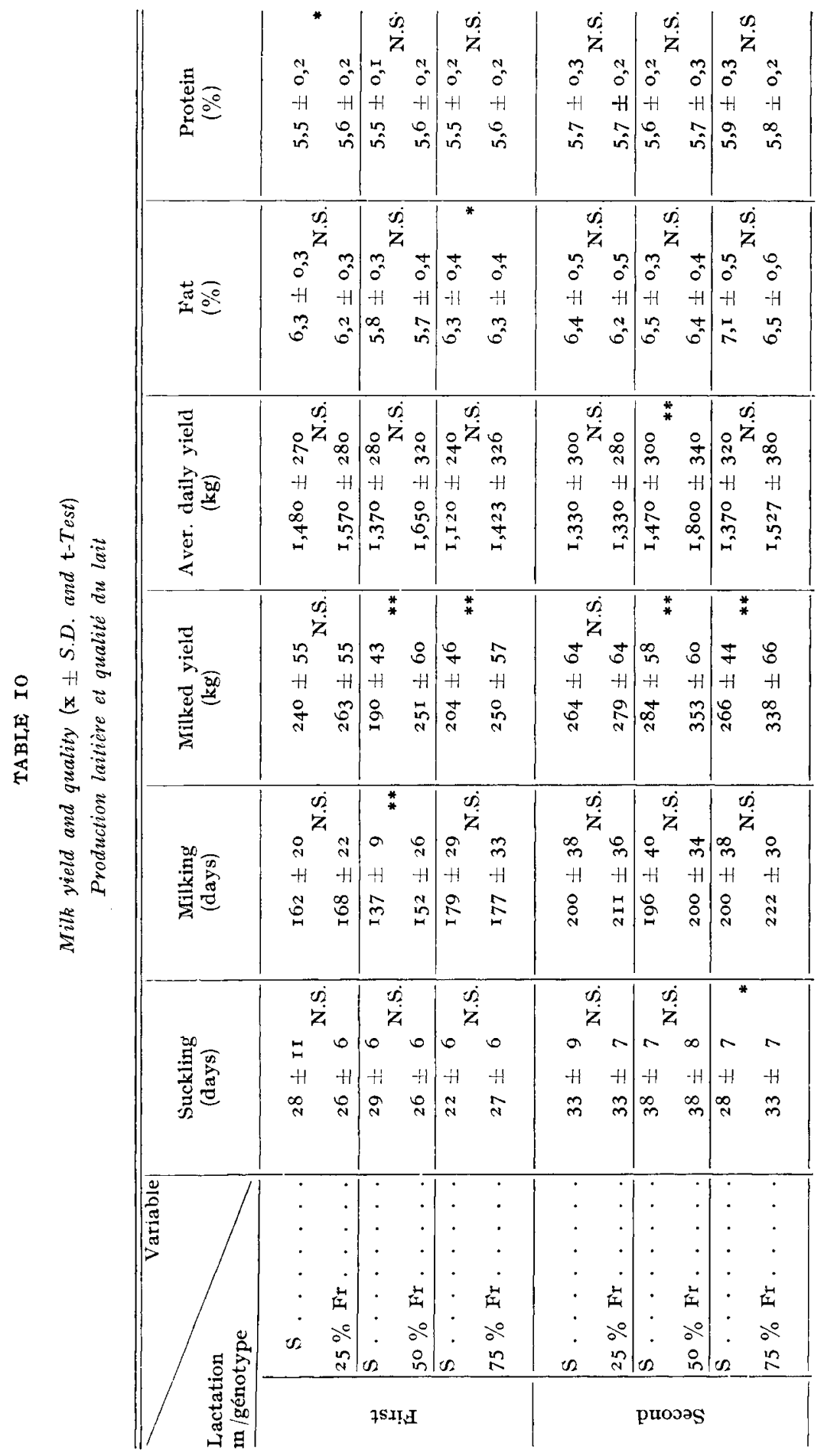




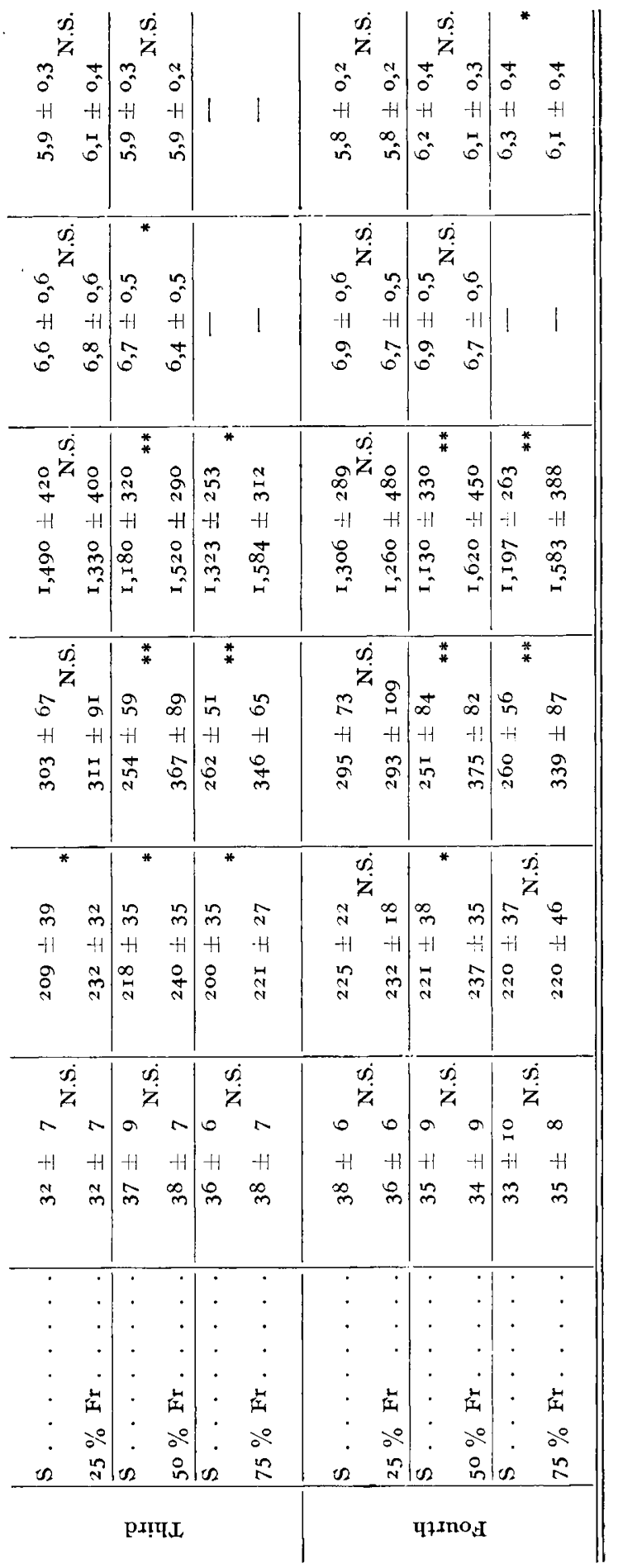


TABLE II

Milk yield and quality (standard lactation)

Production laitière et qualité du lait (lactation type)

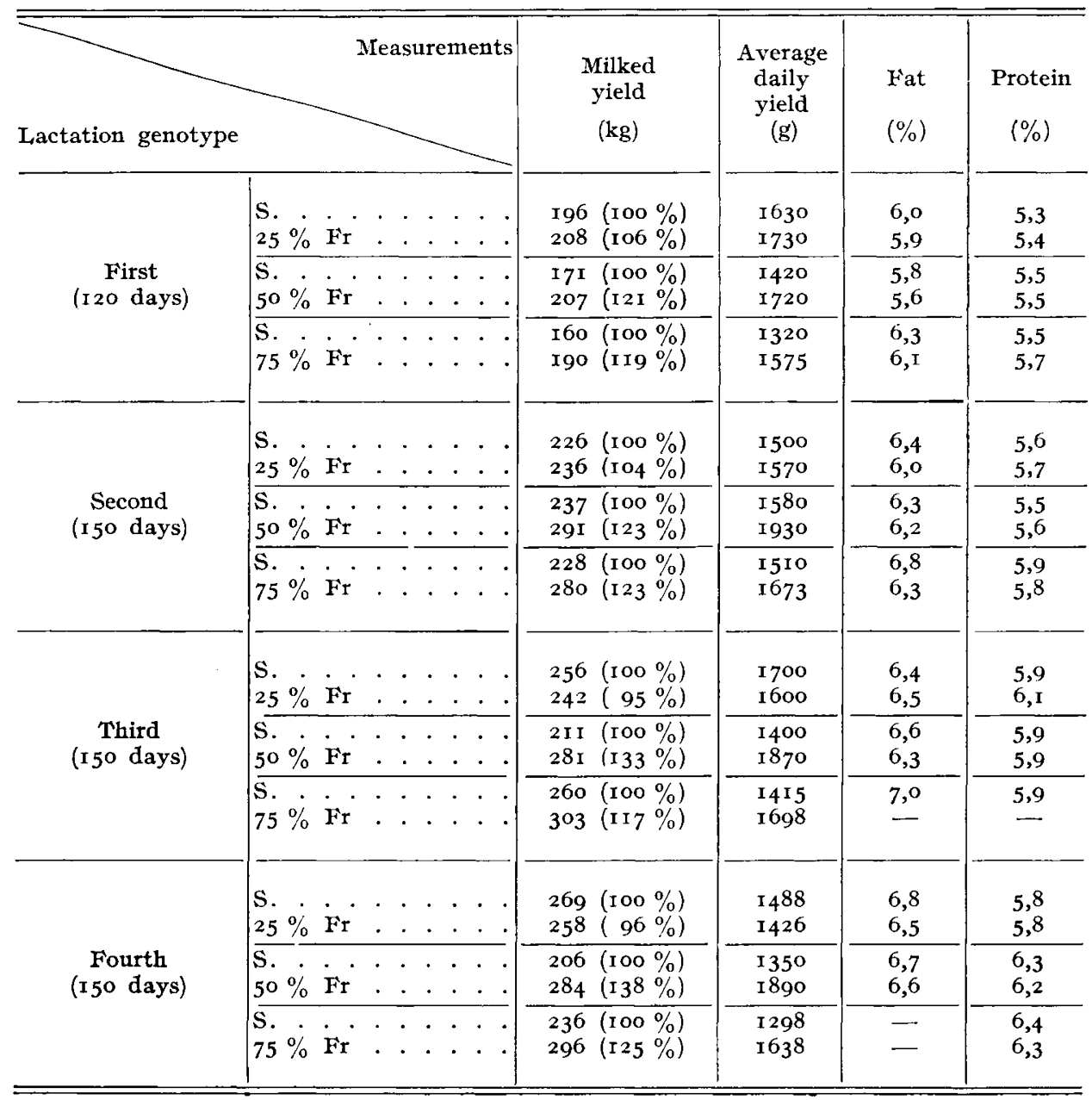

table Io, while that of the standard lactations (I20 days of milking for the first lactation and $\mathrm{I}_{50}$ for the other three lactations) is given in table II.

As expected under the intensive rearing conditions of the experiment, the milked yield of the crossbreds is higher than that of the purebred Sarda, after a suckling period of nearly a month for the first lactation and over a month $( \pm 35$ days) for the adult lactations. Three interesting comments should be made at this stage:

- There is no significant difference (not even at the first lactation) between the milk yield of the $25 \mathrm{p}$. Ioo Fr and their contemporary Sardas.

- Strictly speaking, the best dairy ewe of the four genotypes appears to 
TABLE I2

Maximum recording (cc) and date (expressed in days after birth; $\overline{\mathbf{x}} \pm$ S.D.)

Date (exprimée en jours après la mise-bas) et quantité de lait au controle maximum (cc)

\begin{tabular}{|c|c|c|c|c|c|c|c|c|}
\hline \multirow{2}{*}{$\begin{array}{l}\text { Geno- } \\
\text { type }\end{array}$} & \multicolumn{2}{|c|}{ First lactation } & \multicolumn{2}{|c|}{ Second lactation } & \multicolumn{2}{|c|}{ Third lactation } & \multicolumn{2}{|c|}{ Fourth lactation } \\
\hline & Days & cc & Days & cc & Days & $\mathrm{cc}$ & Days & cc \\
\hline $\begin{array}{l}\mathrm{S} . \dot{\mathrm{Fr}} \cdot \\
25 \% \\
\text { Diff.. }\end{array}$ & $\mid \begin{array}{c}74 \pm 26 \\
73 \pm 27 \\
\text { N.S. }\end{array}$ & $\begin{array}{c}I, 892 \pm 350 \\
I, 965 \pm 353 \\
\text { N.S. }\end{array}$ & $\begin{array}{c}67 \pm \mathrm{I} 6 \\
69 \pm 27 \\
\text { N.S. }\end{array}$ & $\left\{\begin{array}{c}1,944+323 \\
2,018 \pm 3^{1} 3 \\
\text { N.S. }\end{array}\right.$ & $\mid \begin{array}{c}65 \pm 2 \mathrm{I} \\
68 \pm \mathrm{r} 8 \\
\text { N.S. }\end{array}$ & $\begin{array}{c}2,242 \pm 436 \\
2,104 \pm 581 \\
\text { N.S. }\end{array}$ & $\mid \begin{array}{ccc}66 \pm 23 \\
47 \underset{* *}{ \pm}\end{array}$ & $\left\{\begin{array}{c}2, \mathrm{I} 45 \pm 408 \\
2, \mathrm{IIO} \pm 777 \\
\text { N.S. }\end{array}\right.$ \\
\hline $\begin{array}{l}\text { S. } . \dot{\text { Fr. }} \\
50 \% \\
\text { Diff. . }\end{array}$ & $\mid \begin{array}{c}88 \pm 26 \\
92 \pm 28 \\
\text { N.S. }\end{array}$ & $\begin{array}{c}1,686 \pm 370 \\
2,086 \pm 37^{2} \\
* *\end{array}$ & $\mid \begin{array}{c}72 \pm 34 \\
88 \pm 5 I \\
\text { N.S. }\end{array}$ & $\left\{\begin{array}{r}1,995 \pm 369 \\
2,438 \pm 477 \\
* *\end{array}\right.$ & $\begin{array}{c}70 \pm 19 \\
72 \pm 26 \\
\text { N.S. }\end{array}$ & $\begin{array}{c}\mathrm{I}, 858 \pm 4 \mathrm{II} \\
2,326 \pm 45^{8} \\
* *\end{array}$ & $\left|\begin{array}{c}71 \pm 27 \\
76 \pm 43 \\
\text { N.S. }\end{array}\right|$ & $\left\{\begin{array}{l}1,845 \pm 480 \\
2,399 \pm 585 \\
* *\end{array}\right.$ \\
\hline $\begin{array}{l}\text { S. } \\
75 \% \text { Fr. } \\
\text { Diff.. . }\end{array}$ & $\begin{array}{l}66 \pm 20 \\
90 \pm 4^{8}\end{array}$ & $\left\{\begin{array}{l}\mathrm{I}, 586 \pm 347 \\
\mathrm{I}, 89 \mathrm{I} \pm \mathrm{F}_{* *}^{ \pm 04}\end{array}\right.$ & $\mid \begin{array}{cc}60 & \pm \mathrm{I} 8 \\
98 & \pm 63 \\
* * & 6\end{array}$ & $\mid \begin{array}{c}2,03 \mathrm{I} \pm 426 \\
2, \mathrm{I} 56 \pm 466 \\
\text { N.S. }\end{array}$ & $\mid \begin{array}{c}61 \pm 22 \\
68 \pm 24 \\
\text { N.S. }\end{array}$ & $\begin{array}{c}r, 997 \pm 334 \\
2,279 \pm 462 \\
*\end{array}$ & $\begin{array}{c}70 \pm 20 \\
93 \pm 57 \\
\text { N.S. }\end{array}$ & $\begin{array}{c}1,789 \pm 334 \\
1,854 \pm 591 \\
\text { N.S. }\end{array}$ \\
\hline
\end{tabular}

TABLE 13

Distribution of the udders according to type and genotype (see fig. 4) Distribution des mamelles d'après leur type et le génotype des brebis (voir fig. 4)

\begin{tabular}{|c|c|c|c|c|}
\hline Genotype Type & $\begin{array}{c}I \\
(\%)\end{array}$ & $\begin{array}{c}2 \\
(\%)\end{array}$ & $\begin{array}{c}3 \\
(\%)\end{array}$ & $\begin{array}{c}4 \\
(\%)\end{array}$ \\
\hline s....... & $4, \mathrm{I}$ & $3 I, 4$ & $6 \mathrm{r}, 2$ & 3,3 \\
\hline $50 \% \mathrm{Fr} .$. & 33,3 & 44,4 & 22,2 & - \\
\hline $75 \%$ Fr. . . & $4^{2,9}$ & - & $57, \mathrm{r}$ & - \\
\hline
\end{tabular}

be the $50 \mathrm{p}$. Ioo $\mathrm{Fr}$; this confirms the information obtained from other similar Mediterranean projects (Flamant, r974; Kalaissakis et al., I977; Flamant and CASU, I977). The indication is that there is a drop in absolute and relative milk production when arriving at the $75 \mathrm{p}$. Ioo Friesian blood level. This is clearer from the complete lactation data (table I2) than from the standard lactation data (table 13 ). It will eventually be interesting to compare this information with the data of the $87,5 \mathrm{p}$. Ioo Fr genotype-which, unifortunately, is not yet available. 
- Contrary to Greek findings (KaLAIssakis et al., r977), there is no significant difference between the different crossbred genotypes and their contemporary purebred groups in respect of milk quality (fat and protein content), although as expected, the milk of the purebreds is richer in fat content than that of the contemporary crossbreds (tables ro and II).

There is no significant difference between the lactation periods of the crossbreds and the purebreds, although the purebreds on average always show a relatively shorter lactation period than their contemporary crossbreds, which could be attributed to the slightly earlier average date of lambing of the crossbreds (fig. 2).

\section{f. - Lactation curves}

An investigation within genotype and number of lactation of the average date on which the first milk records were effected, very seldom shows differences between the comparable genotypes (crossbreds and contemporary Sardas) from one year to another. Whenever a difference does occur, however, the average date of the first milk recording of the crossbreds-which is naturally linked to the date of lambing--is always the earlier of the two.

It is also interesting to note that the first milk recording (linked to the date of lambing) of the truly adult lactations (3rd and 4th) is always carried out in January and early February, within a period of one month. On an average, the first controls of the second lactation take place a month later (February and early March). The average duration of the milking period of the crossbreds is comparable to the milking periods for similar crossbreds in other parts of the Mediterranean.

- The following observations can be made on the lactation curves (fig. 3):

- There is considerable similarity between the total quantity of the milked yield of the Sardas and the $25 \mathrm{p}$. Ioo Fr (table Io). However, the initial yield by the $25 \mathrm{p}$. roo $\mathrm{Fr}$ crossbreds at the beginning of lactation (after weaning) is higher and the final yield at the end of lactation (IIth to I 7 th control) is lower than that of their contemporary Sardas. This applies parti-
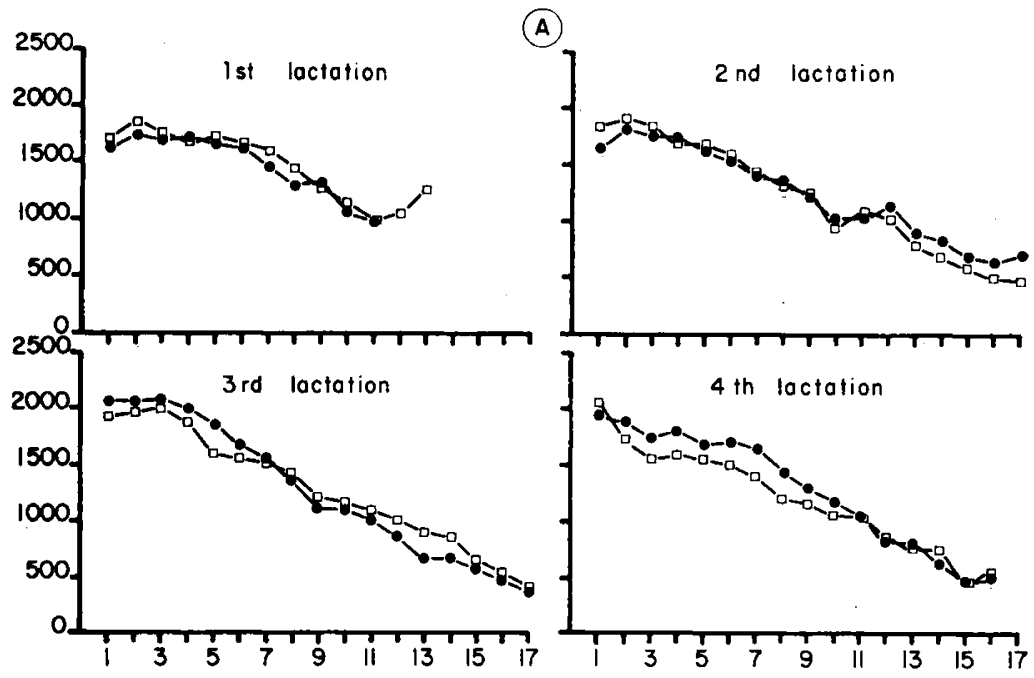

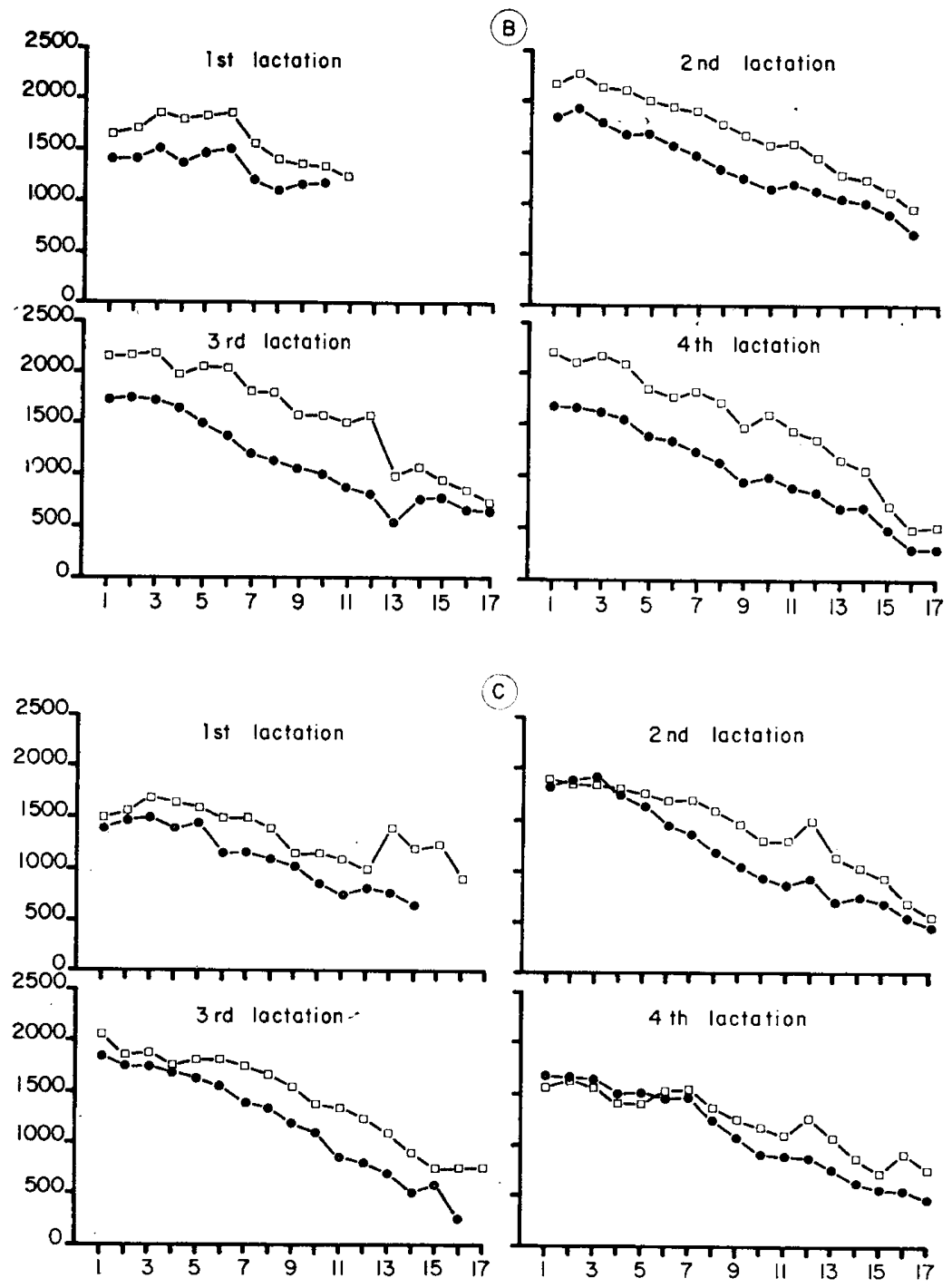

FIG. 3. Lactation curves.

A) $25 \%$ Friesian ewes compared to contemporary Sarda.

B) $50 \%$ Friesian ewes compared to contemporary Sarda.

C) $75 \%$ Friesian ewes compared to contemporary Sarda.

Courbes de lactation

A) Brebis $25 \%$ Frison comparées à des contemporaines Sardes.

B) Brebis $50 \%$ Frison comparées à des contemporaines Sardes.

C) Brebis $75 \%$ Frison comparées à des contemporaines Sardes.

Sarda

Sarde

Friesian cross $\square$

Croisées Frison 
cularly to the 2nd-4th lactations, whereas no noteworthy differences exist for the Ist lactation.

- A comparison of the lactation curves between the $50 \mathrm{p}$. Ioo Fr and their contemporary purebreds is always to the advantage of the crossbreds. The two lactation curves tend to be similar in evolution, but the individual milk controls of the crossbreds are consistently between 200-500 gm higher than those of the purebreds. This confirms the value of $F_{1}$ ewes under intensive rearing conditions.

- The results of the comparison between the $75 \mathrm{p}$. Ioo $\mathrm{Fr}$ and the Sardas are far less striking, since the two lactation curves ( $S$ and $75 \mathrm{p}$. IOo $\mathrm{Fr}$ ) are almost identical, particularly after the third lactation. The two groups of ewes in all cases start at a very comparable level of production, differing only towards the $7^{\text {th }}$ or 8 th control effected at about I40-I50 days from lambing.

A study of the maximum recordings (table $\mathrm{I} 2$ ) confirms the relatively late stage at which the Sarda ewe attains her maximum daily yield. It is interesting to note that some of the crossbreds also reach maximum yield rather late in comparison with results obtained with purebred Friesians elsewhere (BoyAzoGLU, 9663). KALAISSAKIS et al. (I977) arrive at similar conclusions with their Friesian $\times$ Chios crossbreds, but at a much earlier stage after birth (adult lactations, 45-60 days vs. 70-9o days in our case; $F_{1}$ and 75 p. roo Fr material). The fact that the maximum daily yield is attained at such a late stage could at least partially be ascribed to problems in adapting to machine milking.

With regard to the maximum recording data, two main remarks can be made:

- The negligible difference between the purebred Sarda and the $25 \mathrm{p}$. roo Fr can be confirmed. The volume of the maximum daily yield and the interval between birth and maximum yield are similar for these two genotypes.

- There are highly significant differences (PL o.oI) between the volume of the maximum recording only in the case of the $\mathrm{S} / 50 \mathrm{p}$. Ioo Fr comparisons, while in the $\mathrm{S} / 75 \mathrm{p}$. I00 $\mathrm{Fr}$ comparisons, this is only true for the first lactation (also difference at PL 0.05 ewes in the third lactation).

Comparisons of the yield of the Préalpes and Friesian crossbreds (50 p. roo and $75 \mathrm{p}$. IOO) in the very short ascending period of the lactation curve (IzQUIERDO PRIMO et al., I969) show that maximum recorded yield was lower for the 75 p. roo crossbreds than for the $50 \mathrm{p}$. roo and that, contrary to our data, the crossbreds attain their maximum recorded yield at an earlier stage than the purebred Préalpes.

\section{g. - Milking ability and machine stripping}

Machine milking is essential to the development of the dairy industry under intensive husbandry conditions. It is thus important to consider the udder conformation of breeds to be used under these conditions. A valuable presentation of the udder conformation of the Sardinian breed was made by SANNA and. PrCINELII (I973) and for comparative purposes, an attempt was made here to classify the different genotypes in our experiment according to the type of udder (fig. 4). Observations made at Bonassai with a random sample of contemporary Sardinian and crossbred ewes (50 p. Ioo Fr and $75 \mathrm{p}$. IOo $\mathrm{Fr}$ ) show that while only 4 p. roo of the controlled purebred ewes had the "hard" type of udder, the comparative values for the $50 \mathrm{p}$. Ioo Fr was $33 \mathrm{p}$. roo and that for the $75 \mathrm{p}$. Ioo 

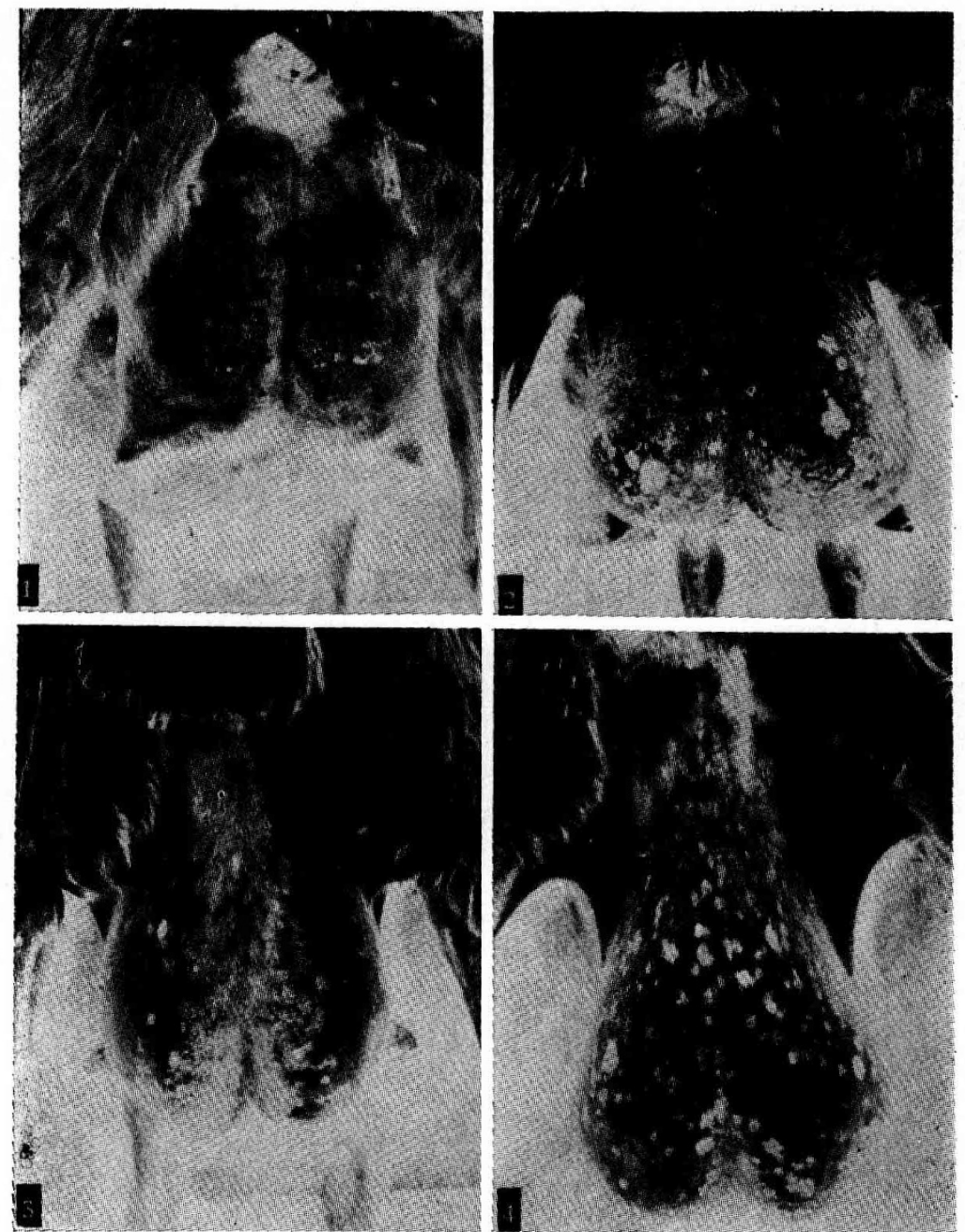

FIG. 4. - Main udder types.

Principaux types de mamelles.

Fr nearly 43 p. Ioo. In the light of the observations of PARTE ARroyo and FLAMAN'T (r978), this could be interpreted as indicating a better average milking ability of the purebreds, despite a less attractive udder conformation in general and some milk retained in the udder after each milking (table I3).

The relation between the facility of machine milking, milk retention, etc., on the one hand, and the form of the udder, hardness, general conformation and position of the teats, on the other, is a very complex matter, approached by the farmer (" éleveur" in French) and the milker ("trayeur" in French) in different ways. In a recent publication, PARTE ARroyo and Flamant (I978) used three criteria to evaluate the milking ability of ewes of three dairy genotypes (Lacaune, Sarda and the F.S.L., the result of a Friesian, Sarda and Lacaune cross): milking characteristics, udder conformation and loss in milk production in relation to 
the reduction in the number of daily milkings. The milking characteristics of the Sarda ewes are apparently the least adequate, with the highest percentage of milk retained following udder massage. However, the average loss in production (one versus two milkings) is the least significant. Under simplified milking conditions, the F.S.L. ewes appear to have inherited the most favourable factors from their parental breed, the Sarda, at the same time maintaining the better udder conformation of the Lacaune breed.

According to CASU and RUDA (I973), machine stripping has little economic value under the local (even intensified) husbandry conditions. A study was consequently undertaken on the different genotypes to determine the quantity of milk obtained through stripping (table I4). The information thus obtained confirms their findings and indicates that in the case of the purebred Sardas and the $25 \mathrm{p}$. Ioo Fr and $50 \mathrm{p}$. Ioo Fr crossbreds, the percentage of milk obtained through stripping is less than 5 p. Ioo of the total milk yield; it is higher for the 75 p. IOo Fr group of ewes (6,8 p. Ioo: Ist lactation; 5,3 p. I00: 2nd lactation; 5,4 p. roo: 3 rd lactation). Even when referring to the standard lactation period, the 75 p. IOo Fr group always shows the highest quantity and relative percentage of stripped milk.

TABLE I4

Comparative value of machine stripping

Valeurs comparées de la repasse

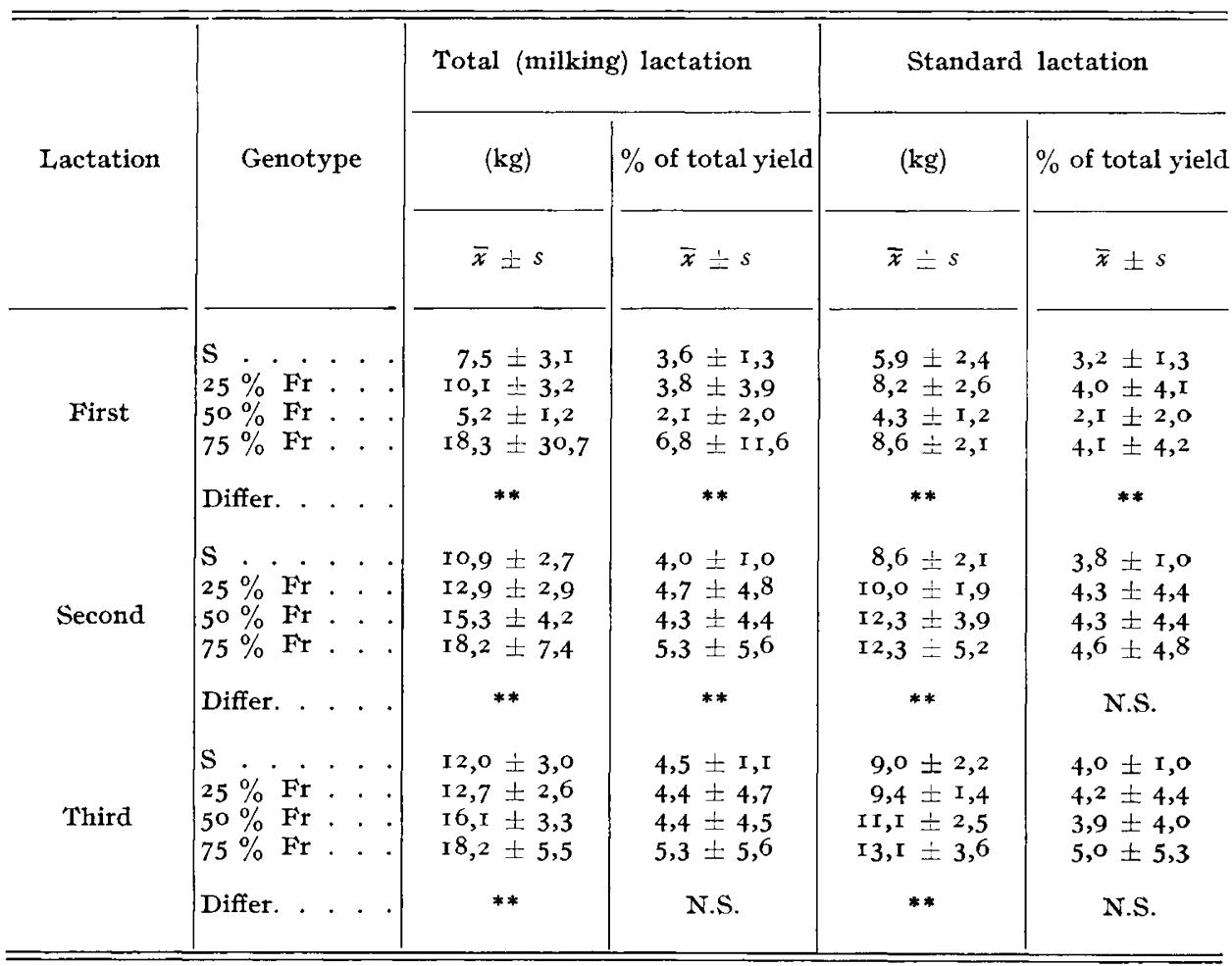




\section{h. - Wool characteristics}

Carpet wool production still plays an important role on the island where carpet weaving is traditional, particularly in the light of the recent re-activation of the family operated carpet industry. The development of tourism in recent years created a growing market for all handwoven textiles and the determined action of the local institute for popular arts (ISOLA) revived the interest in carpet weaving and local textile production.

The basic material for the traditional carpet industry has always been the wool of the longwool Sarda dairy breed, known for its high staple length, convenient
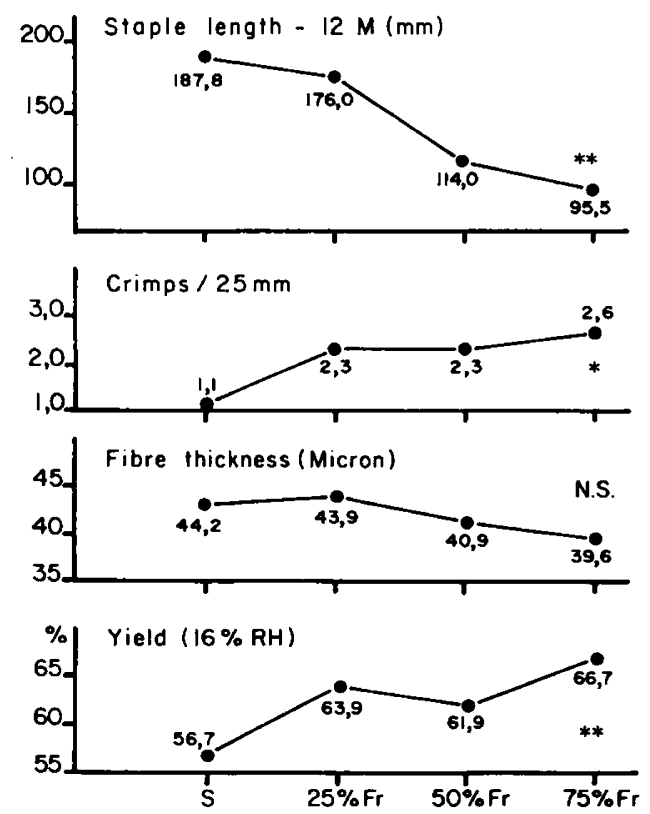

FIG. 5. - Wool characteristics.

Caractéristiques lainières.

TABLE I5

Wool quantity (kg)

Quantité de laine $(\mathrm{kg})$

\begin{tabular}{c|c|c|c|c|c|c}
\hline \hline Genotypecomp. & $\mathrm{S}$ & $25 \% \mathrm{Fr}$ & $\mathrm{S}$ & $50 \% \mathrm{Fr}$ & $\mathrm{S}$ & $75 \% \mathrm{Fr}$ \\
\hline Lac. period & & & & \\
\hline First . . . . . & $\mathrm{I}, 9 \pm 0,4$ & $2, \mathrm{I} \pm 0,4$ & $\mathrm{r}, 7 \pm 0,3$ & $2,8 \pm 0,5$ & $2,0 \pm 0,4$ & $2,9 \pm 0,8$ \\
\hline Second. . . . . & $2,0 \pm 0,4$ & $2,0 \pm 0,3$ & $\mathrm{I}, 7 \pm 0,4$ & $2,9 \pm 0,6$ & $2, \mathbf{I} \pm 0,6$ & $3,7 \pm 0,9$ \\
\hline
\end{tabular}


fibre thickness and crimp value. Its quality and technical possibilities are amongst the best in the Mediterranean Basin (FERRERO, I972). It thus appears important to have an indication of the effect of crossbreeding on wool quality and type.

The average of the data obtained is presented in figure 5. It is evident that, despite the higher average quantity of shorn wool (table I5) from the crossbreds, the wool is less suitable for carpet weaving than that of the purebreds. It will undoubtedly be interesting to undertake a future study on the variability of the different measurements when a more representative number of animals will be available.

\section{Discussion and conclusion}

I. The analysis and publication of the results obtained in Sardinia complete the crossbreeding experiments carried out over the past twenty years between the East Friesian brefd and a number of the local Mediterranean breeds: the Areassi in Israel, the Chios in Greece and the Préalpes (Lacaune type) in France. In general, these experiments were aimed at finding a genotype likely to improve the cheese industry and fully exploit the investments in the dairy sheep industry (machine milking, husbandry buildings and other facilities) undertaken in the richer agricultural areas (cereal planted plateaus and irrigated plains). By eliminating most of the constraints pertaining to the traditional animal husbandry systems, it is, in fact, fossible to use more demanding animal material, however with all the productive qualities: milk yield, numerical productivity, high growth rate of the lambs, etc. It has been customary to use the East Friesian breed in improved husbandry conditions to correct the shortcomings of the local breeds, such as:

- low numerical productivity of the Awassi and Sarda breeds;

- low growth capacities of the Awassi, Sarda and Chios breeds, and the fat-tail of the $A$ wassi breed;

- low milk yield (Préalpes-Lacaune), average milk yield (Sarda) or high milk yield, but lower than that of the purebred East Friesian (Chios).

The East Friesian undoubtedly possesses all the above qualities in its own environment, but experiments as a whole reveal certain qualities specific to the local breeds and which might deteriorate by crossbreeding with the Friesian breed. These qualities essentially concern adaptability in difficult environments, which better husbandry conditions have not or cannot completely correct: resistance to heat due to strong thermic variations (FLAMANT and RICORDEAU, r 969 ), possibility of out-of-season sexual activity whereby the natural growth of the grass in autumn and spring can be used (Goot, I966; ZERVAS et al., I 975). It can also be assumed that the high nutritional requirements of the East Friesian or its crossbreds are not always satisfied, even under improved husbandry conditions. Frequent sanitary problems are found in the purebred Friesian or the crossbred $75 \mathrm{p}$. Ioo Friesian ewes.

The experiments with the Sarda breed confirm, however, that under certain improved and controlled conditions, the defects of the East Friesian can be reduced. Thus, sexual seasoning observed elsewhere with an increased proportion of Friesian blood (ZERVAS et al., I975) was not found in the Sardinian experiments and the sanitary problems appear less frequently with the crossbreds than indicated, for 
example, by Goot (I966), Ricordeau and Flaman't (1969) and Zervas et al. (I975). The observations of SHIMSHONI and LAVI (I972) in Israel, ZERVAS et al. (r975) in Greece and Flamant and CASU (I977) in the Roquefort region (France) confirm our own observations; through various methods of flock management a farmer can attain a certain amount of success. In general, the rearing of ewes with over 50 p. Ioo of Friesian blood cannot be recommended without risking setbacks.

The lower productivity of crossbred Friesian ewes beyond the first generation $\left(F_{1}\right)$ is due to the influence of unfavourable factors at several levels (KALAIsSA KIS et al., I977):

- on the reproduction efficacy, resulting in a decrease in the birth rate of lambs and the milk yield of ewes;

- on the viability of the crossbred lambs and adults;

- on the level of milk yield per lactation, either through a direct effect on the lactation curve or its level at different stages (IzQUIERdo PRIMo et al., I969), or through an indirect effect: the reproductive ability and viability as an intermediary, determining the number of reproductive females available for renewal and consequently a possible rate of selection.

2. In comparison with the other Mediterranean sheep breeds, the Sarda has other particularities: milking ability and interesting fleece characteristics.

Observations made on the morphology of the udder and the milk fractions collected during milking were not really conclusive with regard to the milking ability of the various crossbred genotypes in comparison with the Sarda ewes. They thus had to be submitted to the same experimental schemes, whereby stripping was suppressed or a single daily milking was carried out, thus revealing the particularities of the Sarda ewes in comparison with other breeds (CASU et al., r978).

With regard to the fleece characteristics, the East Friesian crossing undeniably lowers the qualities required for carpet making. Crossbreeding thus has to be accompanied by the regional planning of the area concerned. It can, for example, be considered limiting the rearing of crossbred ewes in the irrigated plains, however maintaining the rearing of Sarda ewes in the extensive and mountainous regions covering most of the island ( $\mathrm{L}_{\mathrm{E}}$ LANNOU, I94I). The combination of farming with the local breed and a homecraft industry, technologically linked to it and likely to bring about an important increase in value, probably constitutes one of the conditions for the perpetuation of rural society in this region. On the contrary, farms in the irrigated plains can undertake specialised dairy and meat production (CASU, I97I).

3. Through these results different crossbreeding strategies can be foreseen for farmers having undertaken a degree of improvement. It is thus possible to compare the milk yield of the following flocks, taking a $20 \mathrm{p}$. Ioo renewal rate of the flock into account (table 16 ):

a) purebred Sarda,

b) purebred $S a r d a+$ production of the $\mathrm{F}_{1}$ ewe with a second meat crossing,

c) purebred Sarda + production of the $\mathrm{F}_{1}$ ewe + production of the $\Delta_{5} \mathrm{p}$. Ioo Friesian ewes,

d) idem $c$, but with 75 p. Ioo Friesian ewes. 


\section{TABLE I6}

Evaluation of the global productivity of different crossbreeding strategies between the Sarda and Friesian breeds (flocks in equilibrium)

Evaluation de la productivité globale d'après différentes stratégies de croisement entre les races Sarde et Frisonne (troupeaux en équilibre)

\begin{tabular}{|c|c|c|c|}
\hline \multirow{2}{*}{ Genotype } & \multirow{2}{*}{$\begin{array}{l}\text { Relative proportion } \\
\text { of the different } \\
\text { genotypes } \\
(\%)\end{array}$} & \multicolumn{2}{|c|}{ Adult ewes in the flock } \\
\hline & & Milk production $(\mathrm{kg})$ & Lambs sold $(n)$ \\
\hline Pure Sarda. . . . . . . . . . . & I 00 & 271 & 67 \\
\hline 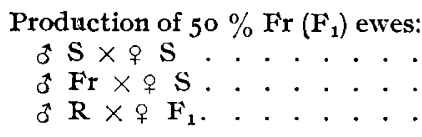 & $\begin{array}{l}19 \\
24 \\
57\end{array}$ & $\left(\begin{array}{c}324 \\
(+20 \%)\end{array}\right.$ & $\begin{array}{c}\text { I I 3 } \\
(+69 \%)\end{array}$ \\
\hline 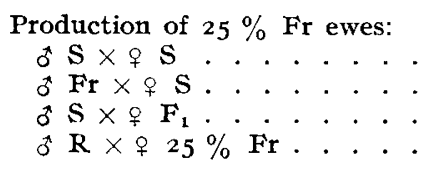 & $\begin{array}{r}6 \\
7 \\
17 \\
70\end{array}$ & $\left(\begin{array}{c}303 \\
+ \text { I } 2 \%\end{array}\right)$ & $\begin{array}{c}\text { I00 } \\
(+49 \%)\end{array}$ \\
\hline 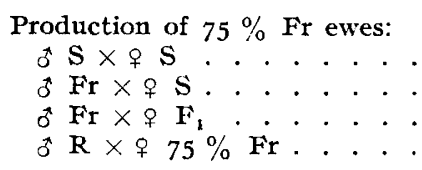 & $\begin{array}{r}6 \\
7 \\
17 \\
70\end{array}$ & $\begin{array}{c}335 \\
(+24 \%)\end{array}$ & $\begin{array}{c}97 \\
(\dashv-45 \%)\end{array}$ \\
\hline
\end{tabular}

In spite of $a \pm 34 \mathrm{p}$. Ioo higher milk yield for $\mathrm{F}_{1}$ ewes in comparison with the Sarda ewes, the global superiority of a flock which would assure the renewal of purebred Sarda females and the production of $F_{1}$ females is only $20 \mathrm{p}$. Ioo. On the other hand, an additional $69 \mathrm{p}$. Ioo of lambs can be sold, which amongst others, have a higher growth rate than the purebred Sarda lambs. It can also be observed that despite a fall in production of the $75 \mathrm{p}$. Ioo Fr ewes, in comparison with $F_{1}$ ewes, the producer centres practising this type of crossbreeding can hopefully use the better milk potential of the East Friesian breed. It must, however, be considered whether the slow progress aimed at is worth the risk engendered by the higher frailty of the genotypes produced, since the production of lambs is generalised in comparison with flocks which are only limited to first generation crossbreeding.

The effective productivity of the flock where the $F_{1}$ ewes are fully used, could be increased by guaranteeing the renewal of the Sarda females through outside purchases or in a satellite flock (under more difficult husbandry conditions) in the mountainous areas. It could also be envisaged to supplement the flocks in the plains with $F_{1}$ females produced directly in the satellite flock (genetic and geographical stratification of breeding systems). A system of this nature, however, 


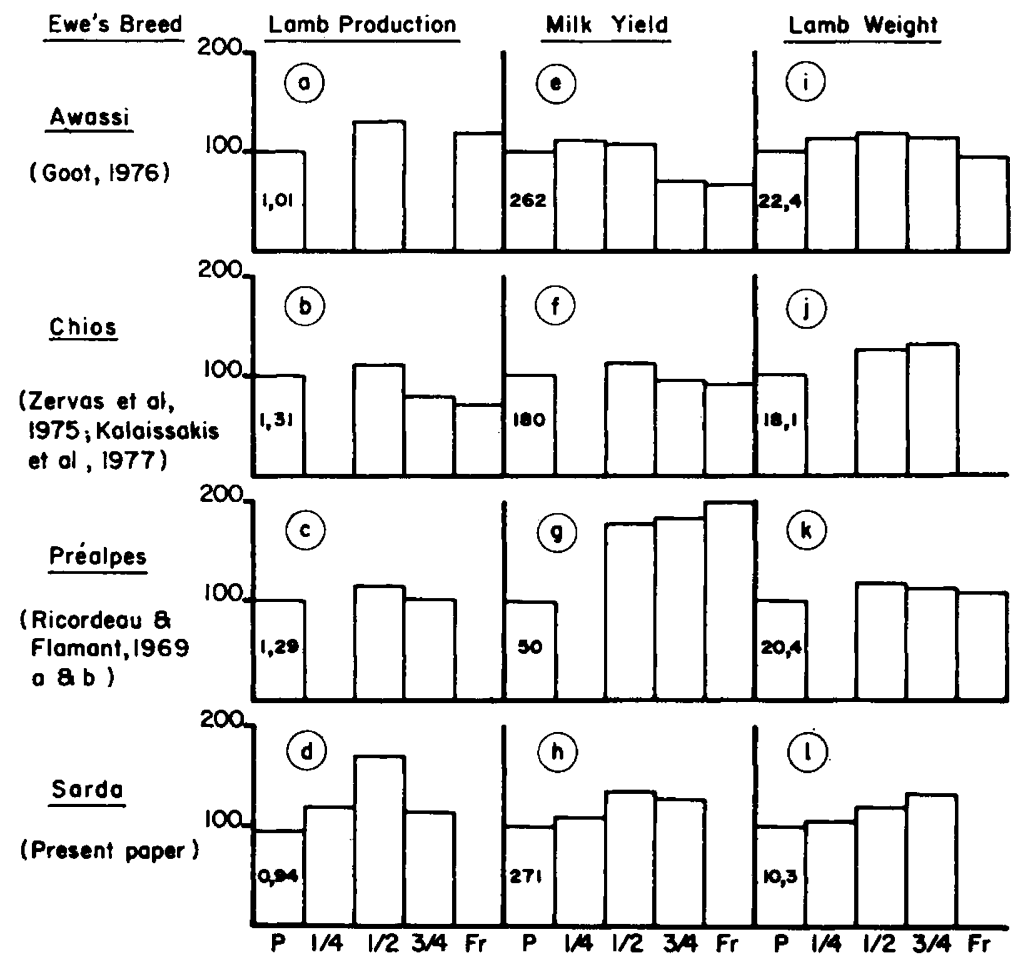

FIc. 6. - Recapitulation of the principal most recent results of grading up to the East Friesian (Fr) with four mediterranean breeds: Awassi, Chios, Préalpes (Lacaune type) and Sarda in reference (percentage) to the pure breed $(P)$.

Récapitulation des principaux résultats récents de croisements de la race Frisonne (Fr) avec quatre races méditerranéennes Awassi, Chios, Préalpes (type Lacaune) et Sarde exprimés en pourcentage des résultats en race pure $(P)$.

$a, c$ : Lambs born per adult ewe present.

Agneaux nés par brebis adulte présente.

$b, d:$ Lambs weaned per adult ewe present.

Agneaux sevrés par brebis adulte présente.

$e, f, h: \mathbf{k g}$ milk per adult lactation.

$\mathrm{kg}$ de lait par lactation adulte.

$g: \mathrm{kg}$ milk during the first 60 days of 2 year old ewe lactations.

: $\mathrm{kg}$ de lait pendant les premiers 60 jours de lactation (brebis de 2 ans).

$i$ : Average weight $(\mathrm{kg})$ of simple male lambs.

Poids vif moyen $(\mathrm{kg})$ d'agneaux mâles simples.

$j$ : Average weight $(\mathrm{kg})$ of $5^{6}$ days old lambs.

Poids vif moyen $(\mathrm{kg})$ d'agneaux de 56 jours.

$k$ : Average weight $(\mathrm{kg})$ of 90 days old lambs.

Poids vif moyen (kg) d'agneaux de 90 jours.

$l$ : Average weight $(\mathrm{kg})$ at weaning.

Poids vif moyen $(\mathrm{kg})$ au sevrage. 
comes up against definite difficulties which, other than organisatory problems, essentially reside in the extremely poor adaptation of East Friesian rams to Mediterranean husbandry conditions and notably with regard to reproduction. This handicap probably also exists under plain conditions and would limit the theoretic effectiveness of the schemes that could be established. In order to solve the adaptation problem of the males under extensive pasture conditions, East Friesian rams were used in Greece mainly for artificial insemination over a period of approximately twenty years (ZERVAS and BoyAzogLU, 1977). Supposing that one even succeeded in mastering the crossbreeding technique and limiting it to the first generation, which was never the case, the global effectiveness of the operation would appear doubtful, since it was not possible to maintain a sufficient number of purebred Friesian flocks and since there was a high rate of mortality amongst the rams in the production centres, necessitating frequent imports.

The crossbreeding experiments with the East Friesian breed undertaken over the past twenty-five years in Israel, France, Greece and Sardinia have thus proved that the use of rams of this breed on a large scale is not to be recommended. It would appear preferable to exploit investments in the Mediterranean region by the creation of synthetic lines where the East Friesian breed can be used (FI AMANT et al., I975: F.S.L. in France, Assaf in Israel), or perhaps even better, if the local breeds possess relatively high productive qualities (Chios and Kyme-Skopelos in Greece) or are characteristically linked to the local economy (Sarda in Italy, Lacaune in France), to establish a purebreed selection programme of these breeds (fig. 6).

Reçu pour publication en mai 1979 .

\section{Acknowledgements}

The authors would like to express their sincere appreciation and thanks to Professors N. ZERVAS and J. MATSOUKAS of the University of Thessaloniki, to Dr. $T$. TREACHER of the Grassland Research Institute (Maidenhead) and to Mr. J. C. Mocouor of I.N.R.A. (Jouy-enJosas) for their valuable suggestions in the preparation of the final text.

\section{Résumé}

\section{Croisement entre les races ovines Sarde et Frisonne en Sardaigne}

Le développement de l'irrigation dans les plaines a ouvert ces dernières années des possibilités de production agricole intensive dans plusieurs régions de Sardaigne. On s'est demandé si l'élevage des brebis laitières pouvait valoriser cette amélioration; un programme de recherches sur la possibilité d'élever des brebis laitières dans des conditions intensives a donc été envisagé et entrepris à l'Istituto Zootecnico e Caseario per la Sardegna. Il s'agit notamment de déterminer le type génétique le plus adapté à cette nouvelle situation. Les investissements importants exigés par ce type d'amélioration ne peuvent être valorisés que par l'obtention d'un haut niveau de productivité individuelle.

La brebis Sarde, dont la productivité est normalement satisfaisante dans les conditions d'élevage extensif de l'intérieur de l'île présente certains inconvénients dans des conditions alimentaires plus intensives :

— fécondité relativement basse,

- capacité limitée de croissance des agneaux.

Du point de vue de la production laitière on peut également rechercher le génotype réalisant la transformation la plus efficace. A cet effet, il a été décidé d'essayer un croisement avec la race Frisonne qui parmi toutes les races laitières présente le potentiel de production laitière le plus élevé ainsi qu'une grande fécondité dans son pays d'origine. 
Néanmoins, tenant compte des difficultés d'adaptation que cette race rencontre normalemient en dehors de son milieu d'élevage d'origine, il a été réalisé un schéma expérimental qui ne se limite pas au croisement de première génération $\mathrm{F}_{1}$, mais réalise une deuxième génération de croisemients vers les races parentales (Sarde et Frisonne). Les animaux ainsi obtenus $\left(\mathbf{F}_{1}\right.$, I /4 Frisonne, $3 / 4$ Frisonne) ont été comparés à des brebis de race Sarde strictement contemporaines et conduites de façon identique.

Les résultats confirment l'information obtenue dans d'autres parties du bassin méditerranéen (France, Grèce, Israel, Portugal, Espagne, Turquie) : même dans des conditions de nutrition et d'élevage les meilleures possibles — du fait de la température élevée et du climat sec régnant dans le milieu méditerranéen — il n'est pas profitable et dans la plupart des cas même pas recommandé d'élever des brebis avec plus de 50 p. 100 de sang Frison.

Les observations Sardes démontrent à nouveau la fragilité de la race Frisonne et de ses produits de croisement au delà de la première génération, même si les résultats obtenus dans les conditions d'irrigation intensive des plaines n'atteignent pas le même niveau catastrophique enregistré lorsque la race Frisonne est utilisée dans des conditions d'élevage plus difficiles. En outre dans le cas de la Sardaigne, le croisement Frison risque d'être extrêmement. préjudir iable à une activité économique très importante pour les régions de l'intérieur : le tissage artisanal des tapis Sardes. En ce qui concerne la facilité de la traite des observations complémentaires sont nécessaires pour préciser l'incidence du croisement Frison sur une qualité essentielle des brebis Sardes.

La comparaison avec les différents résultats d'amélioration génétiques réalisés depuis vingt ans en Israel, Grèce et France nous incite à penser que seules deux voies sont possibles pour les élevages de brebis laitières méditerranéennes : la sélection et l'utilisation en race pure des races locales, la création de lignées synthétiques ne présentant pas plus de 50 p. I oo de sang Frison.

\section{Références}

BATICLE Y., I974. L'élevage ovin dans les pays européens de la Méditerranée occidentale. Publ. Université de Dijon, XLVII. Soc. Belles Lettres, Paris, France, 229-268.

BOYAZOGLU J., I963. Aspects quantitatifs de la production laitière des brebis. I. Mise au point bibliographique. Ann. Zootech., 12, 237-296.

BuitKamp, I952. Umfang, Leistungen und Fruchtbarkeitsverhältnisse der ostfriesischen Milchschafzucht. Tierzüchter, 4, 535-537.

CASU S., I97r. Allevamento ovino da latte in Sardegna. Situazione attuale e possibilità di evoluzione. Options Méditerranéennes, 7, 100-106.

Casu S., Boyazoglu J., Ruda G., r978. Essai sur la traite mécanique simplifiée des brebis Frisonnes-Sardes. Proceedings, Symposium sur la traite mécanique des petits ruminants, Alghero, Italia (in print).

CASU S., RudA G., 1973. Suppression de l'égouttage manuel des brebis Sardes traites à la machine. Symp. traite mécanique Petits Ruminants, Millau, 7-I I mai I973. Ann. Zootech. (1974), horssérie, I33-I35.

Casu S., Sanna A., VAIRA G., 1976. Résultats des recherches effectuées en Sardaigne sur le croisement industriel pour la production d'agneaux. Bull. techn. Dép. Génét. anim. (I.N.R.A., Fr.), 25, 65-87.

Cosseddu E., Sanna A., Sanna L., I972. La produzione dell'agnello bianco in Sardegna. L'Inform. A grar., 37, Ior9r-ror95.

Cremer E., I934. Uber die Herkunft des ostfriesischen Milchschafes. Dtsch. landw. Tierz., 38, $666-667$.

CUMLIVSKI B., I976. Reproduction and adaptation abilities of the East Friesian sheep in the C.S.R. Proceedings, 27 th Annual Meeting, E.A.A.P., Zurich, Switzerland.

DIJKstra R. G., 1966. Is it desirable to maintain a population of Friesian milk sheep? (in Dutch). Veeteelt-en Zuivelber., 9, 230-232.

Dimakopoulos J., r960. The best adapted breeds of sheep. Meeting, Prod. Utiliz. Sheep Goat Milk, F.A.O./E.A.A.P., Athens, Greece.

Domingos Borrero J., I968. First results of crossing East Friesian and Serra da Estrela Bordaleiro in the district of Oliveira do Hospital (in Portuguese). Bolm pecuar., 36 (I), 309-3 I 5.

EBbinghaus H., I949. Der Milchschafzüchter. Anleitung zur Durchführung einer erfolgreichen Milchschafzucht und -haltung für Schafbesitzer und Züchter-vereinigungen. Metta Kinan Verlag Nachf., Luneburg, Deutschland. 
Eyal, E., GooT H., 1968. Vital statistics and milk and lamb production of $F_{1}$ ewes (Awassi $\times$ East Friesian) under farm conditions (in Hebrew). Pamph. Volcani Inst. agvic. Res., No I24. Abstract in Animal Breeding, Abstracts.

F.A.O., r977. Mediterranean cattle and sheep in crossbreeding. Animal Production and Health, Publication No 6, 37 pp.

FerRero Mercedes Viale, 1972. Rave carpets from East and West. Orbis Books, London, Fngland.

Flamant J. C., 1974. Performances des brebis croisées en vue de la production laitière à la traite. Proceedings, I ${ }^{\text {er }}$ congrès Mondial de Génétique appliqué à l'élevage, Madrid, Espagne.

Flamant J. C., Boyazoglu J., Casu S., Espejo M., Valis OrTiz M., Zervas N., i976. Inventaire et exploitation du patrimoine héréditaire des populations ovines méditerranéennes. Options méditerranéennes, 35, 56-75.

Flamant J. C., Casu S., I977. Différences entre races pour le potentiel de production laitière et amélioration génétique de cette production. Proceedings, 28th Annual Meeting, E.A.A.P., Bruxelles, Belgique.

Flamant J. C., Coste E., Fayot M. F., Ferrie H., 1975. Amélioration génétique de la production laitière des brebis par l'utilisation de la race Frisonne. Journées Rech. Ovine Caprine (Paris), I 73-1 80.

Flamant J. C., JacQuin Michèle, I978. Unpublished data.

Flamant J. C., Ricordeau G., I969. Croisements entre les races ovines Préalpes du Sud et Frisonne (Ostfriesisches Milchschaf). I. La brebis laitière de Frise Orientale. Élevage en race pure. Utilisation en croisements. Ann. Zootech., 18, I07-130.

Fox C. W., Choukiri E., ChabaAN R., I976. The results of crossbreeding between Chios and the local fat-tail Awassi. Proceedings, 27th Annual Meeting, E.A.A.P., Zurich, Switzerland.

GooT H., I966. Studies on the native Awassi sheep and its crosses with the exotic East Friesian milk sheep (in Hebrew). Pamph. Nat. Univ. Inst. Agric. Rehovot., No I $_{5}$.

Goor H., 1976. Scientific activities 1971-1974. Institute of Animal Science, A.R.O. (Israel), 30.

Grofnevel,D H., I953. Die männlichen Blutlinien der ostfriesischen Milchschafzucht. Vet. med. Dissertation, Tierärztl., Hannover, Deutschland.

HAFEZ E.S.E., x953. Puberty in female fa:m animals. Emp. J. Exp. Agric., 21, $217-225$.

Izquierdo Primo J. A., Flamant J. C., Ricordead G., I969. Étude préliminaire de la phase ascendante de la courbe de lactation des brebis traites. Ann. Zootech., 18, I69-I 84 .

Kalaissakis P., Papadimiriou T., Flamant J. C., Boyazoglu J. G., Zervas N., i977. Comparaison des races ovines Chios et Frisonne avec leurs croisements en Grèce continientale. II. Production laitière. Ann. Génét. Sél. anim., 9, I 81-201.

KATSAOUNIS N. K., I972. Some observations on the productivity of imported sheep breeds and their croossbreds with Greek breeds (in Greek). Epistimoniki Epitiris Ktiniatrikis Sholis Thessalonikis, 12, I94-420.

LANTINGA J. H., I96r. The milk production of dairy sheep in Zeeland (in Dutch). Veeteelten Zuivelber., 4, 372.

Le Lannou M., I94I. Pâtrcs et paysans de la Sardaigne. La Zattera, Fratelli Cocco, Cagliari, Italia.

Manunta G., CASU S., I968. Sull'attività sessuale della pecora di razza Sarda nei diversi periodi dell'anno. Zootech. $e$ Vet., 22, 249-256.

MUHIBERG, r934. Das ostfriesische Milchschaf. Dtsch. landw. Tierz., 38, 698-699.

Papadopoulos G., Kalaissakis P., Zervas N., Papadimitriou T., i972. Étude des vaces de Chios, de Frise Orientale et de leurs croisements dans la région de l'Attique. II. Croissance des agneaux (en Grec). Rapport spécial. Ministère de 1'Agriculture (Athènes). Polygr., 2 I pp.

PAR'm ARRoyo Ana Maria, Flamant J. C., I978. Caractéristiques moyennes de traite et de mamelle de trois génotypes de brebis laitièves. Proceedings, Symposium sur la traite mécanique des petits ruminants, Alghero, Italia (in print).

Ricordeau G., Flamant J. C., I969a. Croisements entre les races ovines Préalpes du Sud et Frisonne (Ostfriesisches Milchschaf). II. Reproduction, viabilité, croissance, conformation. Ann. Zootech., 18, I3I-r 49.

Ricordeau G., Flamant J. C., I969b. Croisements entre les races ovines Préalpes du Sud et Frisonne (Ostfriesisches Milchschaf). III. Performances laitières. Ann. Zootech., 18, I5I-I68.

SanNa A., Picineliti G., 1973. Morphologie de la mamelle chez les brebis Sardes. Symp. traite mécanique Petits Ruminants, Millau, 7-I I mai 1973. Ann. Zootech. (1974), hors série, 5 I-53.

SANNA A., RUdA G., r97o. Produzione dell'agnello pesante in Sardegna: primi risultati sperimentali. Giornate di studio. Istituto Zoot. e Caseario per la Sardegna, Sassari Italia.

SchEINGRABER M., I933. Der Wert des Schafes als Milchtier unter besonderer Berücksichtigung der verschiedenen Milchschafrassen und ihrer Leistungen. Z. Züchtg., 28, 85-124, 233-270.

ScheINGRABER M., I934. Milchschafrassen. $Z$. Schaf $z$, . 23, I97-205, 232-236.

SHIMSHONI A., LAVI A., I972. Several veterinary and zootechnical aspects in the breeding of East Friesian sheep and their crosses. Symp. Milk Recording Practices Sheep Goats, Tel-Aviv, Israel. 
SONMEZ R., 1977. Comparison of milk yield and prolificacy between native sheep and Ost Friz crossbreeds in Turkey. Proceedings, 28th Annual Meeting, E.A.A.P., Brussels, Belgium. STEPHAN E., I96r. On the effect of lighting on reproduction in East Friesian sheep (in German). Giessen. Sehr Reine Tierz. Haustiergenet., 1, 39-43.

TANEv I., Donchev P., Khristov M., r97I. Formation of dairy sheep (in Bulgarian). Süzdavanie na mlechno ovtsevüdstvo. Zhivotnovodstvo, 25 (I I), 25-29.

TANev I., Efrimova L., Iotov C., I968. East Friesian sheep at the Vidin Research Station (in Bulgarian). Zhivotnovodstvo, 22 (Io), 54-57.

Walrave Y., Can'tin P., Desvignes A., Thimonien J., I975. Variations saisonnières de 1'activité sexuelle des races ovines du Massif Central. Journées Rech. Ovine Caprine (Paris), 26 I-27I. ZEEB R., I934. Das ostfriesische Milchschaf. Dtsch. landw. Tierz., 38, 534-536.

ZEEB R., I94I. Erfolgreiche Milchschafhaltung. Seibeneichen-Verlag, Berlin, Deutschland. Abstract in Züchtungskunde, 18, 31-32.

Zervas N., Boyazoglu J. G., I977. L'élevage en Grèce : Présent et Avenir. Ethnozootechnie, 18, $73 \mathrm{pp}$.

Zervas N., Boyazoglu J., Kalaissakis P., Papadimitriou T., Flamant J. C., i975. Comparaison des races ovines Chios et Frisonne avec leurs croisements en Grèce continentale. I. Viabilité et reproduction. Ann. Génét. Sél. anim., 7, 277-29r. 